\title{
Self-regulated learning of history-taking
}

Citation for published version (APA):

Wagner-Menghin, M. (2019). Self-regulated learning of history-taking: Looking for predictive cues . [Doctoral Thesis, Maastricht University]. ProefschriftMaken Maastricht. https://doi.org/10.26481/dis.20190925mw

Document status and date:

Published: 01/01/2019

DOI:

10.26481/dis.20190925mw

Document Version:

Publisher's PDF, also known as Version of record

\section{Please check the document version of this publication:}

- A submitted manuscript is the version of the article upon submission and before peer-review. There can be important differences between the submitted version and the official published version of record.

People interested in the research are advised to contact the author for the final version of the publication, or visit the DOI to the publisher's website.

- The final author version and the galley proof are versions of the publication after peer review.

- The final published version features the final layout of the paper including the volume, issue and page numbers.

Link to publication

\footnotetext{
General rights rights.

- You may freely distribute the URL identifying the publication in the public portal. please follow below link for the End User Agreement:

www.umlib.nl/taverne-license

Take down policy

If you believe that this document breaches copyright please contact us at:

repository@maastrichtuniversity.nl

providing details and we will investigate your claim.
}

Copyright and moral rights for the publications made accessible in the public portal are retained by the authors and/or other copyright owners and it is a condition of accessing publications that users recognise and abide by the legal requirements associated with these

- Users may download and print one copy of any publication from the public portal for the purpose of private study or research.

- You may not further distribute the material or use it for any profit-making activity or commercial gain

If the publication is distributed under the terms of Article $25 \mathrm{fa}$ of the Dutch Copyright Act, indicated by the "Taverne" license above, 
The research reported here was carried out at Maastricht University in Leaning!

in the School of Health Professions Education

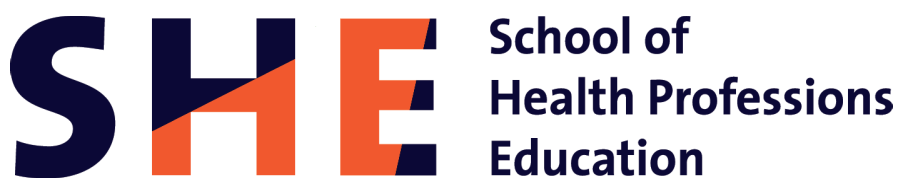




\title{
Self-regulated learning of history-taking: Looking for predictive cues
}

\author{
DISSERTATION
}

To obtain the degree of Doctor at Maastricht University, on the authority of the Rector Magnificus Prof. Dr. Rianne M. Letschert in accordance with the decision of the Board of Deans, to be defended in public on

Wednesday, 25th of September 2019, at 10.00 hours

by

Michaela Wagner-Menghin 


\section{Supervisors}

Prof. Dr. Jeroen (J.J.G.) van Merrienboer

Prof. Dr. Anique (A.B.H.) de Bruin

\section{Assessment committee}

Prof. Dr. Mirjam (M.G.A.) Oude Egbrink (Chair)

Prof. Dr. Martin (M.R.) Fischer (Ludwig Maximilians Universität, Munich, Germany)

Dr. Esther (E.J.W.) Giroldi

Dr. Janneke (J.E.) van de Pol (Utrecht University)

Prof. Dr. Jan Joost (J.J.) Rethans 
"We are who we are because of what we learn and what we remember" E.R. Kandel 



\section{Content}

Chapter 1 General Introduction 9

$\begin{array}{lll}\text { Chapter } 2 \text { Understanding the mechanism of self-monitoring } & 19\end{array}$

$\begin{array}{lll}\text { Chapter } 3 \text { Capturing how students use cues } & 41\end{array}$

$\begin{array}{lll}\text { Chapter } 4 \text { Differences in students' cue-utilisation } & 65\end{array}$

$\begin{array}{lll}\text { Chapter } 5 \text { Supervisors'cue-utilisation } & 81\end{array}$

$\begin{array}{lll}\text { Chapter } 6 \text { General Discussion } & 101\end{array}$

$\begin{array}{lll}\text { Appendix } & \text { English Summary } & 119\end{array}$

Nederlandse samenvatting $\quad 125$

Valorisation Addendum 133

Acknowledgements 139

Curriculum Vitae $\quad 141$

SHE Dissertation Series $\quad 145$ 


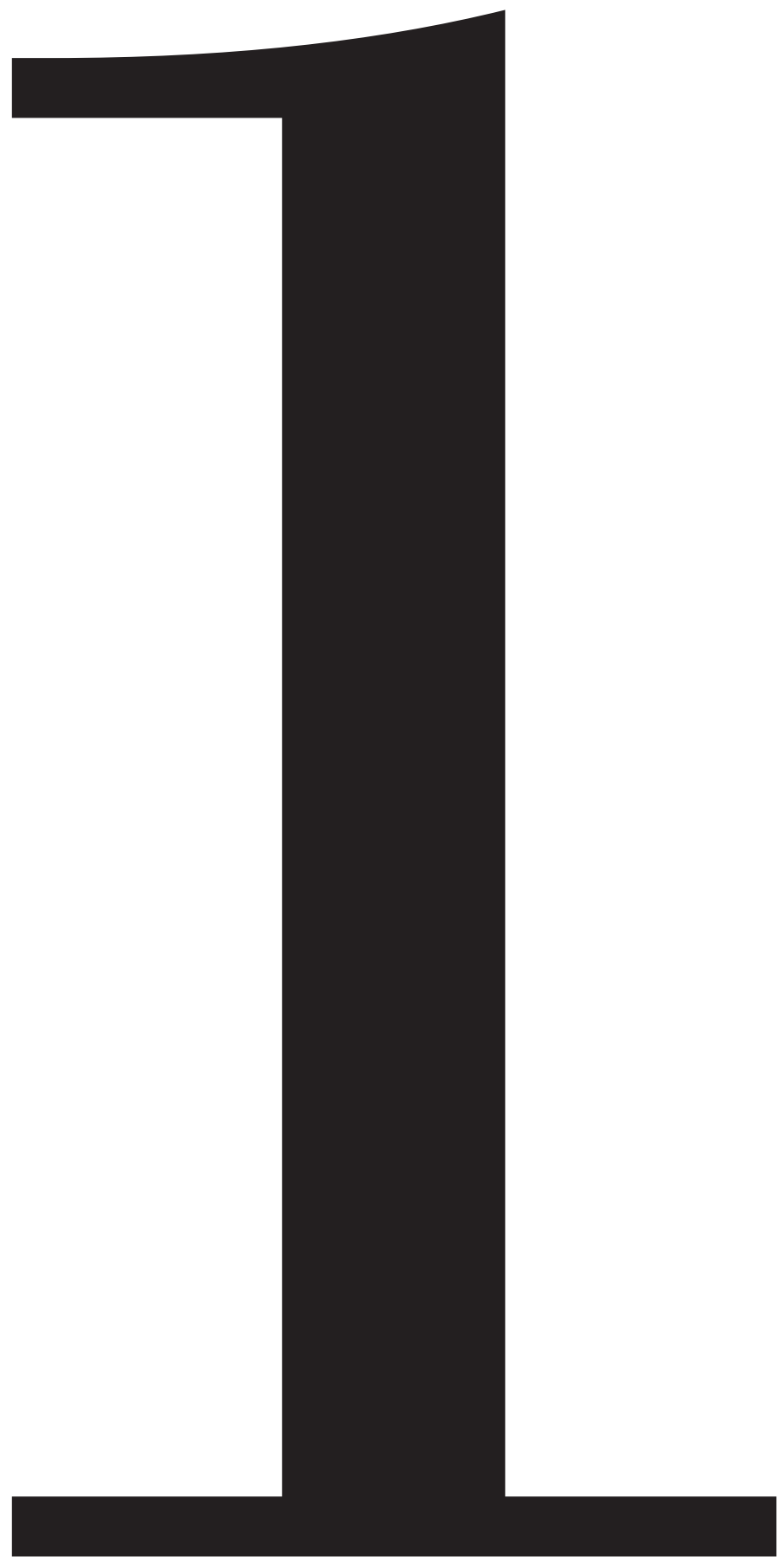


Chapter 1

General introduction 
Chapter 1 
In medical history-taking two persons, a patient and a doctor, communicate in a given medical setting, such as the outpatient department in a hospital, to address the patient's problem. ${ }^{1-3}$ Effective and good communication during history-taking is crucial in making a correct diagnosis ${ }^{4,5}$ and to negotiate a treatment plan with the patient. ${ }^{6}$ Effective communication also helps patients adhere to treatment plans. ${ }^{7}$ Moreover, it has positive effects on the doctors' well-being. ${ }^{8}$ Communication is labelled as effective and good when three conditions are fulfilled. First, the doctor needs to succeed in balancing his or her needs and the patient's needs within the requirements of the medical setting. Secondly, the doctor has to structure and steer the communication to facilitate the patient's narrative and elicit the patient's full story. Finally, the doctor has to comprehend the patient's story in order to effectively apply medical knowledge. Although interacting with patients relies heavily on the execution of routine behavioural patterns (e.g., transitioning between phases of the patient-encounter ${ }^{1}$ ), it is also described as a creative, imaginative process (e.g., deciding how to phrase an answer to a patient's question,? experiencing 'this patient is ill' $\left.{ }^{1}\right)$. From a learning sciences perspective this combination of routine aspects and creative, imaginative aspects marks communicating for historytaking as a highly complex skill.

Learning to communicate well with patients for history-taking has already been included in competency frameworks for medical students. ${ }^{10}$ Medical undergraduate students commonly begin practicing comprehensive history-taking in the secure environment of supervised training in a skills laboratory ${ }^{11}$ before transitioning to the more complex real-life setting of workplace-based learning during clerkships. During undergraduate history-taking training in a skills lab, a communication skills supervisor commonly observes the practicing student to give feedback. Feedback given in undergraduate skills training focuses on the improvement of the use of communication skills while trying to work through a comprehensive history-taking guide. ${ }^{11}$ For more advanced students, feedback should not only focus on the use of communication skills but also on the students' hypothesis-driven information gathering. However, this level of history-taking practice usually takes place in the workplace. In this setting the feedback focuses more on the content that was covered rather than on the use of communication skills. $^{12}$

When practicing history taking, reflecting on one's performance boosts the selfregulation of learning, and thus improves performance. Good self-regulation entails monitoring one's own performance, including self-judging one's strengths and weaknesses accurately before acting upon these self-judgements to adapt (i.e., regulate) one's learning. (Figure 1, upper box). Good self-regulation also integrates external feedback on strengths and weaknesses, if available. The importance of accurate self-judgments (= correspondence between self-judgment and external judgment) becomes obvious when external feedback is lacking as it is often the case in workplace-based learning. There, students have to predominantly rely on self-judgements on their performance to 
identify the need for learning and to benefit from their experiences. ${ }^{12-15}$ As this so-called reflection in/on action ${ }^{16}$ requires self-judging one's own performance in every single patient-encounter, educators commonly agree that the ability to identify one's own strengths and weaknesses in communicating with patients is an important educational objective for medical students. For example, in German-speaking countries, this objective is amongst the seven most important learning goals listed for communication training. ${ }^{17}$ The relevance of this learning goal is supported by results establishing accurate self-monitoring judgements as a prerequisite to self-regulated learning, because accurate self-monitoring is needed to select relevant learning activities. ${ }^{18,19}$ Thus, the supervisors' feedback in communication skills training should additionally focus on improving the students' ability to self-judge accurately.

The importance of addressing accuracy in self-judgments becomes ultimately apparent when looking into results concerning students' ability to identify their own strengths and weaknesses. It has been established, mostly in other skill domains, that students are convinced that they are doing better than they actually are. ${ }^{20,21}$ When they self-judge their performance after taking tests, correlations between test performance and self-judgements of performance are at best medium $(r=0.51-0.65) .{ }^{20-23}$ The selfjudgements of medical students on communication skills correspond even less with the ratings given by the faculty $(r=0.19-0.52)^{24-27}$ and also express overconfidence. ${ }^{28}$ Even higher overestimation has been found when students judge their mastery of study materials to predict later performance. Correlations between self-estimated level of text-comprehension and the following tests are low $(r=0.16-0.34),{ }^{29}$ and novices' selfestimated levels of more complex skills (e.g., chess-endgame skills) do not correlate at all with scores on following tests $(r=-0.03-0.07){ }^{30}$

According to basic learning research, these low correlations occur because students use cues, when self-judging performance, that are not indicative (or predictive) of their actual performance. ${ }^{19,31}$ Learners, for example, mistakenly believe that how fast they read a text is an accurate predictor of their understanding of the text. That is, the speed of reading is erroneously used as a cue to self-judge text understanding. In general, learners monitor by consciously and unconsciously using observable cues available in the situation, memory cues (i.e., information and experiences stored in memory) and experiential cues resulting from subjective feelings (Figure 1, grey shapes in the upper box). These cues vary in how predictive they are of actual performance. Applying this to history-taking, a student may observe his/her patient uttering several sentences while smiling friendly (observable cue) in response to an opening question. The student, having phrased an 'open question' as taught in class (memory cue), has the impression that the encounter is running fluently (i.e. s/he uses an experiential cue). Basic learning research also shows that the students' use of more optimal, predictive cues can be stimulated to improve the accuracy of self-judgements. ${ }^{22}$ This is achieved through educational interventions that help students pay attention to predictive cues, 
so called metacognitive prompts. ${ }^{22} \mathrm{~A}$ metacognitive prompt might be a question or a task leading to the emergence of new, more relevant experiential cues. These new cues replace the less predictive experiential cues that originally emerged when performing the task and ultimately better inform the self-judgment of performance. It has to be added that supervisors base their judgment on cues as well. They might also be prone to using unsuitable cues and, therefore, might benefit from using metacognitive prompts as well to judge more accurately and improve their feedback giving.

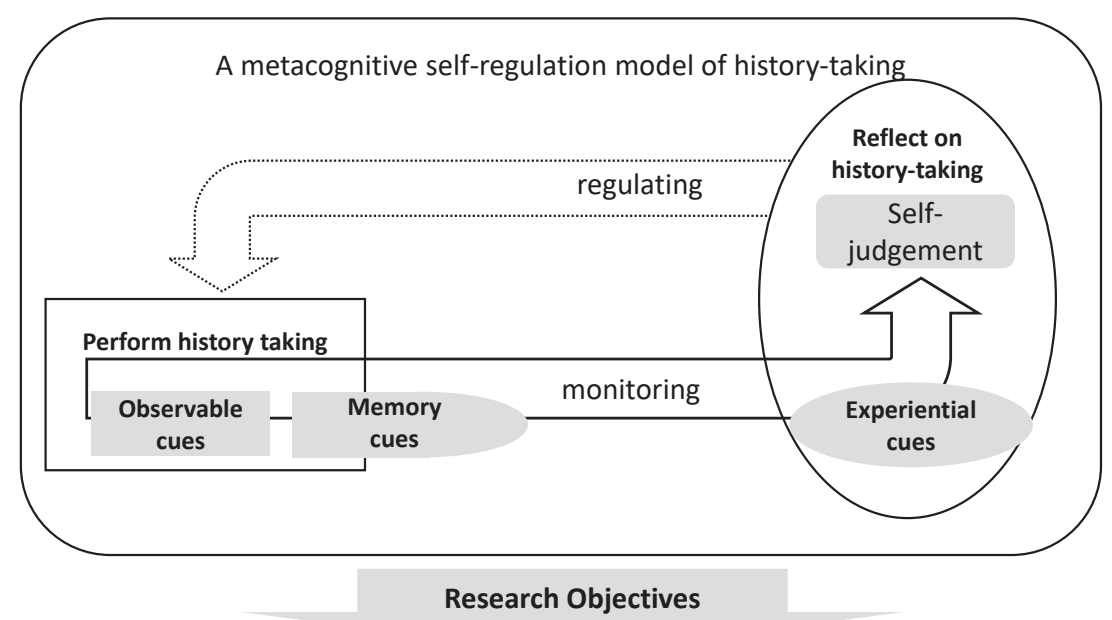

1 Understand the mechanism of self-monitoring as related to patient-communication for history-taking (Chapter 2)

2 Describe how students use cues when self-judging their patient-communication (Chapter $3 \& 4$ )

3 Describe how supervisors use cues when judging others' patient-communication to prepare feedback (Chapter 5)

Figure 1: Research objectives to inform the development of educational design for improving self-judgement of patient-communication when history-taking.

As outlined above, there is a multitude of reasons why medical educators, especially supervisors teaching history-taking skills in the medical undergraduate curriculum, should be interested in the principles of how to improve self-judgments. First, poor self-judgements lead to poor self-regulated learning. ${ }^{18,32}$ Second, poor selfjudgements also have the potential to impede the reception and integration of external feedback, ${ }^{33,34}$ which can lead to poor learning even in a supervised setting. Third, poor 
self-judgements have been shown to be generally quite common in students, and overestimation of one's own performance is a problem in learning history-taking as well. ${ }^{24-27}$ Fourth, poor self-judgements hamper undergraduate medical students' practice of history-taking in the workplace as they are often not directly supervised in these settings. Lastly, poor self-judgments in students might not be the only obstacle in learning history-taking, as supervisors' external judgements depend on cues as well, and their use of inadequate cues might reduce the effectivity of their feedback. G i v e n these negative consequences of poor self-judgments and poor supervisor judgments on the learning of history-taking, there is an urgent need to better understand cue-use in self-judgements and judgments related to learning history-taking. As such, students' monitoring and self-judgement skills should be trained alongside their history-taking skills, to better prepare them for learning in the workplace. And supervisors' judgment skills should be trained to facilitate and improve their feedback giving. But only few results concerning the improvement of students' self-regulation skills in the domain of communicating with patients for history-taking have been presented until now (see ${ }^{24-28}$ for an exception), and no results on student's cue-utilisation, when self-judging historytaking, or supervisors' usage of cues, when giving feedback, are available to inform educational development.

Therefore, the main aim of this project is to gain further insight in how to boost self-regulated learning of history-taking by improving students' and supervisors' use of cues when making self-judgements or judgments of their students' performance.

\section{Dissertation outline}

The forthcoming chapters of this thesis will address the core problem, which is boosting self-regulated learning of history-taking by improving the accuracy of students' self-judgements by setting three objectives (Figure 1, bottom part). Chapter 2 addresses the first research objective, which is to understand the mechanism of self-judgements related to patient-communication. Therefore, literature on cognitive theory on selfmonitoring and complex skill acquisition is compiled in a position paper to understand the mechanisms of self-judgements related to patient communication. A theoretical framework on self-monitoring of patient-communication during history-taking will be presented together with suggestions as to which metacognitive cues improve monitoring.

Chapters 3 and 4 are dedicated to the second objective, which aims to describe how students proceed when self-judging their communication with patients. The study described in Chapter 3 developed a research procedure to capture students' use of cues. It uses the general model on self-monitoring to develop a content coding system in order to systematically describe how students use cues. The study described in Chapter 4 uses the newly developed content coding system to compare how students with superior 
basic clinical skills performance versus poor performers differed with respect to their use of cues.

Chapter 5, covering the third objective, discusses how supervisors proceed when judging students' patient communication. History-taking performance and communication skills are commonly assessed by observing students and rating their performance. Thus, comparing students' self-judgements with supervisor-judgements in order to calculate the degree of accuracy holds the opportunity with sources of error on both sides. In order to pave the way for improving the accuracy of supervisors' external judgements, the general model of self-monitoring is used to empirically explore how supervisors of communication skills monitor their students' history-taking.

Chapter 6 then summarizes and synthesizes the results presented in the previous chapters. It puts them into perspective and considers implications for further development of didactic interventions improving the accuracy of self-judgements and judgements of history-taking. It presents (1) theoretical implications and related future research, (2) limitations or strengths/weaknesses, and (3) practical implications. 


\section{References}

1. Langewitz W. Integration der patientenzentrierten und der arztzentrierten Gesprächsführung. In: Langewitz W, Daetwyler C, Guttormsen-Schaer S, Schnabel K, eds. DocCom Deutsch. Medienunterstützte online Module für die Aus- und Weiterbildung in Kommunikation im Gesundheitswesen. https://doccom.iml.unibe.ch. Bern (Switzerland): Universität Bern; 2014.

2. Smith RC, Hoppe RB. The patient's story: integrating the patient- and physician-centered approaches to interviewing. Ann Intern Med. 1991;115(6):470-477.

3. Silverman J, Kurtz S, Draper J. Skills for Communicating with Patients. Oxford: Radcliffe; 2005.

4. Hampton JR, Harrison MJG, Mitchell JRA, Prichard JS, Seymour C. Relative contributions of history-taking, physical-examination, and laboratory investigations to diagnosis and management of medical outpatients. Br Med J. 1975;2(5969):486-489.

5. Peterson MC, Holbrook JH, Vonhales D, Smith NL, Staker LV. Contributions of the history, physical-examination, and laboratory investigation making in medical diagnoses. West $J$ Med. 1992;156(2):163-165.

6. Chen RC, Clark JA, Manola J, Talcott JA. Treatment 'mismatch' in early prostate cancer - Do treatment choices take patient quality of life into account? Cancer. 2008;112(1):61-68.

7. Zolnierek KBH, DiMatteo MR. Physician Communication and Patient Adherence to Treatment: A Meta-analysis. Med Care. 2009;47(8):826-834.

8. Maguire P, Pitceathly C. Key communication skills and how to acquire them. Br Med J. September 2002;325:697.

9. Salmon P, Young B. Creativity in clinical communication: from communication skills to skilled communication. Med Educ. 2011;45(3):217-226.

10. MFT Medizinischer Fakultätentag der Bundesrepublik Deutschland e. V. (www.mft-online.de) (ed). Nationaler Kompetenzbasierter Lernzielkatalog Medizin [National Competency Framework for Medicine]. In: Berlin: http://www.nklm.de/files/nklm_final_2015-07-03.pdf (Accessed 26.07.2018); 2015.

11. Hartl A, Bachmann C, Blum K, et al. Desire and reality - teaching and assessing communicative competencies in undergraduate medical education in German-speaking Europe - a survey. GMS Z Med Ausbild. 2015;32(5):Doc56.

12. Rosenbaum ME. Dis-integration of communication in healthcare education: Workplace learning challenges and opportunities. Patient Educ Couns. 2017;100(11):2054-2061.

13. Bachmann C, Abramovitch H, Barbu CG, et al. A European consensus on learning objectives for a core communication curriculum in health care professions. Patient Educ Couns. 2013;93(1):18-26.

14. Wouda JC, van de Wiel HBM. The communication competency of medical students, residents and consultants. Patient Educ Couns. 2012;86(1):57-62.

15. Aspegren K. BEME Guide No. 2: Teaching and learning communication skills in medicine - a review with quality grading of articles. Med Teach. 1999;21(6):563-570.

16. Schön DA. The Reflective Practitioner. How Professionals think in Action. Aldershot, GB: Ashgate; 1983. 
17. Kiessling C, Dieterich A, Fabry G, et al. Communication and social competencies in medical education in German-speaking countries: The Basel Consensus Statement. Results of a Delphi Survey. Patient Educ Couns. 2010;81(2):259-266.

18. Dunlosky J, Rawson KA. Overconfidence produces underachievement: Inaccurate self evaluations undermine students' learning and retention. Learn Instr. 2012;22(4):271-280.

19. de Bruin A, Dunlosky J, Cavalcanti RB. Monitoring and regulation of learning in medical education: the need for predictive cues. Med Educ. 2017;51(6):575-584.

20. Ehrlinger J, Johnson K, Banner M, Dunning D, Kruger J. Why the unskilled are unaware: Further exploration of (absent) self-insight among the incompetent. Organ Behav Hum Decis Process. 2008;105(1):98-121.

21. Baker JMC, Dunlosky J, Hertzog C. How Accurately can Older Adults Evaluate the Quality of Their Text Recall? The Effect of Providing Standards on Judgment Accuracy. Appl Cogn Psychol. 2010;24(1):134-147.

22. Thiede KW, Griffin TD, Wiley J, Anderson MCM. Poor Metacomprehension Accuracy as a Result of Inappropriate Cue Use. Discourse Processes. 2010;47(4):331-362.

23. Eva KW, Cunnington JPW, Reiter HI, Keane DR, Norman GR. How can I know what I don't know? Poor self assessment in a well-defined domain. Adv Health Sci Educ Theory Pract. 2004;9(3):211224.

24. Rudy DW, Fejfar MC, Griffith CH, Wilson JF. Self- and peer assessment in a first-year communication and interviewing course. Eval Health Prof. 2001;24(4):436-445.

25. Martin D, Regehr G, Hodges B, McNaughton N. Using Videotaped Benchmarks to Improve the Self-assessment Ability of Family Practice Residents. Acad Med. 1998;73(11):1201-1206.

26. Farnill D, Hayes SC, Todisco J. Interviewing skills: Self-evaluation by medical students. Med Educ. 1997;31(2):122-127.

27. Regehr G, Hodges B, Tiberius R, Lofchy J. Measuring Self-Assessment Skills: An Innovative Relative Ranking Model. Acad Med. 1996;71(10 Suppl):S52-S54.

28. Hodges B, Regehr G, Martin D. Difficulties in recognizing one's own incompetence: Novice physicians who are unskilled and unaware of it. Acad Med. 2001;76(10 Suppl):S87-S89.

29. Dunlosky J, Baker JM, Rawson KA, Hertzog C. Does aging influence people's metacomprehension? Effects of processing ease on judgments of text learning. Psychol Aging. 2006;21(2):390-400.

30. De Bruin A, Rikers R, Schmidt HG. Monitoring accuracy and self-regulation when learning to play a chess endgame. Appl Cogn Psychol. 2005;19(2):167-181.

31. Koriat A. Monitoring one's own knowledge during study: A cue-utilization approach to judgments of learning. J Exp Psychol Gen. 1997;126(4):349-370.

32. Thiede KW, Anderson MCM, Therriault D. Accuracy of metacognitive monitoring affects learning of texts. J Educ Psychol. 2003;95(1):66-73.

33. Sargeant J, Armson H, Chesluk B, et al. The Processes and Dimensions of Informed Self-Assessment: A Conceptual Model. Acad Med. 2010;85(7):1212-1220.

34. Sargeant J, Eva KW, Armson H, et al. Features of assessment learners use to make informed selfassessments of clinical performance. Med Educ. 2011;45(6):636-647. 


\section{Chapter 2}

Improving self-monitoring judgements of communication with metacognitive prompts during history-taking

Michaela Wagner-Menghin Anique B.H. de Bruin Jeroen J.G. van Merriënboer 


$$
3
$$




\title{
Chapter 3
}

\section{Monitoring Patient Communication: Analyzing Judgements of Satisfaction (JOSs)}

\author{
Michaela Wagner-Menghin \\ Anique B.H. de Bruin \\ Jeroen J.G. van Merriënboer
}

Published: Adv Health Sci Educ Theory Pract. 2016 Aug; 21(3):523-40 


\begin{abstract}
Background: Medical students struggle to put into practice communication skills learned in medical school. In order to improve our instructional designs, better insight into the cause of this lack of transfer is foundational. We therefore explored students' cognitions by soliciting self-evaluations of their history-taking skills, coined 'Judgements of Satisfaction (JOSs)'. Our cognitive-psychological approach was guided by Koriat's cueutilisation framework (1997) which rests on the assumption that internal and external cues inform learners' metacognitive judgements, which, in turn, steer their actions. Judgements based on unsuitable cues will cause ineffective behaviour. Consequently, students are unable to adequately master these skills or properly apply them in similar situations.
\end{abstract}

Method: For the analysis, we had 524 medical undergraduates select scenes they were satisfied or dissatisfied with from their video-recorded simulated-patient encounters and explain why. Twenty transcripts were sampled for directed content analysis.

Results: We found that approximately one third of students' judgements focused on content (JOS-type-a); about half on the quality of the communication skills (JOStype-b); and about ten percent targeted the appropriateness of the skills harnessed (JOStype-c).

Conclusion: Lack of reflection on appropriateness may explain why students experience problems adapting to new situations. It was primarily high-performance students who formed type-c judgements; poor performers tended to give type-a and type-b judgements. Future research would benefit from the use of our modified version of Koriat's framework in order to further explore how high and poor performing medical students differ in the way they form JOSs during communications skills training.

Keywords: communicating with patients; directed content analysis; judgement of satisfaction (JOS); metacognitive monitoring; undergraduate medical students. 


\section{Introduction}

Effective communication with patients is crucial in making a correct diagnosis, ${ }^{1,2}$ devising an appropriate treatment plan, ${ }^{3}$ warranting doctors' well-being, ${ }^{4}$ and ensuring that patients adhere to the prescribed treatment. ${ }^{5}$ Learning to communicate effectively, however, requires deliberate practice in challenging settings e.g. ${ }^{6}$ which the medical workplace does not always provide. Medical schools therefore offer training programs with simulated patients aimed to teach students communication process skills, ${ }^{7}$ such as structuring, attentive listening and open-to-closed questioning techniques. When applying these skills to real patients in the clinic, however, students come across different communication cultures and struggle to harmonize the communication techniques they have learned with clinical reality and their personal communication style. ${ }^{8-14}$

As a remedy, it has been suggested that the training setting be more closely aligned with the clinical setting. Yet, patient communication will always require some degree of adaptation, as people differ and, consequently, no two situations will ever constitute a perfect match. Additionally, when something learned cannot be transferred smoothly, previous teaching has not yet succeeded in familiarizing students with relevant underlying principles. This might be traceable not only to the learning environment itself, but also to teachers' and students' way of using it. ${ }^{15}$ The present study therefore seeks to expand the discussion on how to facilitate transfer of communication skills by taking a cognitive-psychological approach. More specifically, we focused on students' metacognitions, as these are important for learning how to apply the underlying communication principles in a new setting (e.g., when moving from classes to clinic, or from patient A to patient B). This approach will help us understand to what extent students have acquired relevant communication principles and how they use them.

Metacognition, originally defined as "thinking about your own thinking and cognitions", ${ }^{16}$ is nowadays often framed within a self-regulation model. It is driven by two processes, monitoring and controlling, that link the actual situation with the knowledge and beliefs stored in the memory of the learner. ${ }^{17}$ Monitoring can be viewed as the internal evaluation process that precedes and informs the controlling of action. As such, metacognition is particularly relevant in patient communication, as it informs adaptation of behaviour during the encounter (reflection in action), while afterwards (reflection on action) it guides further learning or practice. ${ }^{18}$ When a student, for instance, poses an opening question that does not lead to a satisfactory answer, leaving the student with a sense of dissatisfaction (monitoring), he or she may immediately rephrase the question (controlling). After the encounter the student may decide to rehearse a variety of suitable opening questions to better integrate them into the verbal repertoire (controlling learning).

To enact efficient control, however, monitoring needs to be accurate. When a student, for example, evaluates his or her performance too optimistically, inefficient 
Table 1: Translating the cue-utilisation framework from experimental learning research to communicating with patients. Definition of cues and examples

\begin{tabular}{|c|c|c|}
\hline & $\begin{array}{l}\text { source definition and examples: } \\
\text { experimental learning research }\end{array}$ & $\begin{array}{l}\text { translated definition and examples: } \\
\text { communicating with patients }\end{array}$ \\
\hline \multicolumn{3}{|c|}{ Objectively identifiable cues: observable cues (extrinsic cues), OC } \\
\hline Definition & $\begin{array}{l}\text { characteristics observable in the } \\
\text { learning situation }{ }^{25}\end{array}$ & $\begin{array}{l}\text { what was done or said in the situation either } \\
\text { by patient or by the student that can also be } \\
\text { seen or heard by an observer }\end{array}$ \\
\hline \multirow[t]{2}{*}{ Examples } & $\begin{array}{l}\text { trials/time used for studying a learning } \\
\text { material/text }\end{array}$ & student asks a series of closed questions \\
\hline & $\begin{array}{l}\text { number of arguments used to generate } \\
\text { a summary about a text }\end{array}$ & $\begin{array}{l}\text { the patient answers in a low voice with one- } \\
\text { worded answers }\end{array}$ \\
\hline \multicolumn{3}{|c|}{ Objectively identifiable cues: memory cues (intrinsic cues), MC } \\
\hline \multirow[t]{2}{*}{ Definition } & $\begin{array}{l}\text { cues referring to beliefs and knowledge } \\
\text { in memory }\end{array}$ & $\begin{array}{l}\text { explicitly mentioned knowledge and beliefs } \\
\text { when elaborating on a judgement }\end{array}$ \\
\hline & & $\begin{array}{l}\text { Such statements can be reliably identified } \\
\text { by probing if the to be coded statement } \\
\text { sounds like an answer in a knowledge test on } \\
\text { communication skills. }\end{array}$ \\
\hline \multirow[t]{3}{*}{ Examples } & $\begin{array}{l}\text { semantic relatedness of learning } \\
\text { material [related (poker-flush) or } \\
\text { unrelated (dog-spoon) }]^{25}\end{array}$ & $\begin{array}{l}\text { start the information gathering with an open } \\
\text { question" (mental model) }\end{array}$ \\
\hline & $\begin{array}{l}\text { short -term memory representation of } \\
\text { text [verbatim sentences] }]^{27}\end{array}$ & $\begin{array}{l}\text { "have several versions of suitable opening } \\
\text { questions available to use according to first } \\
\text { impression of patient" (mental model) }\end{array}$ \\
\hline & $\begin{array}{l}\text { long- term memory representation of } \\
\text { text [inferences made based on text] }]^{27}\end{array}$ & $\begin{array}{l}\text { "try another opening question, when patient } \\
\text { has not started talking or looks puzzled" } \\
\text { (cognitive strategies) }\end{array}$ \\
\hline \multicolumn{3}{|c|}{ mnemonic cues/subjective feelings (SF) } \\
\hline Definition & $\begin{array}{l}\text { Unconscious processing of observable } \\
\text { cues and memory cues which is } \\
\text { experienced as subjective feeling. This } \\
\text { unconscious cognitions are translated } \\
\text { in a verbal expression in the form of an } \\
\text { object's attribute }^{38}\end{array}$ & $\begin{array}{l}\text { verbal elaborations including adjectives } \\
\text { indicating that a comparison to an internal } \\
\text { standard has taken place }\end{array}$ \\
\hline Example & $\begin{array}{l}\text { ease of text processing during reading - } \\
\text { "It is easy to recall this list of words" } \\
\text { ease of retrieval when deriving the self- } \\
\text { judgement }{ }^{25}\end{array}$ & $\begin{array}{l}\text { "this question appears to be inappropriate" } \\
\text { "I have chosen a suitable transition statement" }\end{array}$ \\
\hline
\end{tabular}


learning behaviour (e.g., premature interruption of study or practice) and low learning outcomes will result. ${ }^{19-25} \mathrm{~A}$ better insight into the monitoring process may help improve its accuracy. The cue-utilisation framework introduced by Koriat ${ }^{25}$ is useful to guide this insight: It states that learners form judgements by consciously and unconsciously selecting and processing different types of cues that the situation emits (cues = signals or hints one can percept in the situation, Table 1; left column).

To refer to judgements emerging from monitoring satisfaction with performing complex skills, we here introduce the term judgement of satisfaction (JOS). In the example above, observations (the patient provides too little information) and subjective feelings (discontent with the information obtained) are the cues that trigger student's negative JOS (= dissatisfaction) which in turn cause the student to adopt a different strategy.

Because not all cues at hand are equally relevant, misjudgements occur. Fortunately, when it comes to learning from text, we can guide students to select relevant cues. Strategies for this include activating relevant cues by having students reread a text, ${ }^{26}$ generate summaries ${ }^{21}$ and utilize keywords, ${ }^{27}$ as well as de-activating irrelevant cues by delaying monitoring until initial reading experiences (e.g., time spent and ease of reading) have disappeared from working memory. When the new objectively identifiable cues (length of summary) and new subjective feelings (ease of retrieval and processing fluency) remain, monitoring accuracy improves as these cues better predict the (quantifiable) degree of comprehension. ${ }^{27}$

Despite these insights on text comprehension, knowledge about how learners actually use cues to form JOSs when communicating with patients is scant, and there is a paucity of techniques facilitating the use of communication-specific cues. A study by Martin, Regehr, Hodges, McNaughton ${ }^{28}$ revealed that monitoring improved after students had reviewed four videos showing other students interviewing a patient $(\mathrm{r}=0.38$ before vs. $\mathrm{r}=0.52 \mathrm{after}$ ) as it helped them to better understand the assessment criteria and differences in performance. How students processed cues to bring about such effect was not explored. In a similar vein, Hawkins et al. ${ }^{29}$ found that students' self-evaluation of their suturing performance improved (from $r=0.48$ to $r=0.83$ ) after having been shown several performances of other students on video. What deserves attention in this context is that student's monitoring accuracy influences how a supervisor delivers feedback to the student ${ }^{30}$ and what the student gains from this feedback. ${ }^{31}$ Knowing this, it becomes all the more important that we enhance students' monitoring accuracy during patient communication. However, before being able to do so, we need to know which communication-specific cues they use when forming a JOS and what themes these cues focus on.

In addition to building on Koriat's cue-utilisation framework ${ }^{25}$, the present research will draw on theoretical principles from a conversational model for doctorpatient communication outlined by Silverman, Kurtz, Draper. ${ }^{32}$ Central to this model is the notion that content aspects and process skills should be combined adaptively to 
integrate doctor's and patient's position. The new, combined model has been visualized in Figure 1 where the quadripartite arrow illustrates there are four types of cues involved that may influence students' JOS.

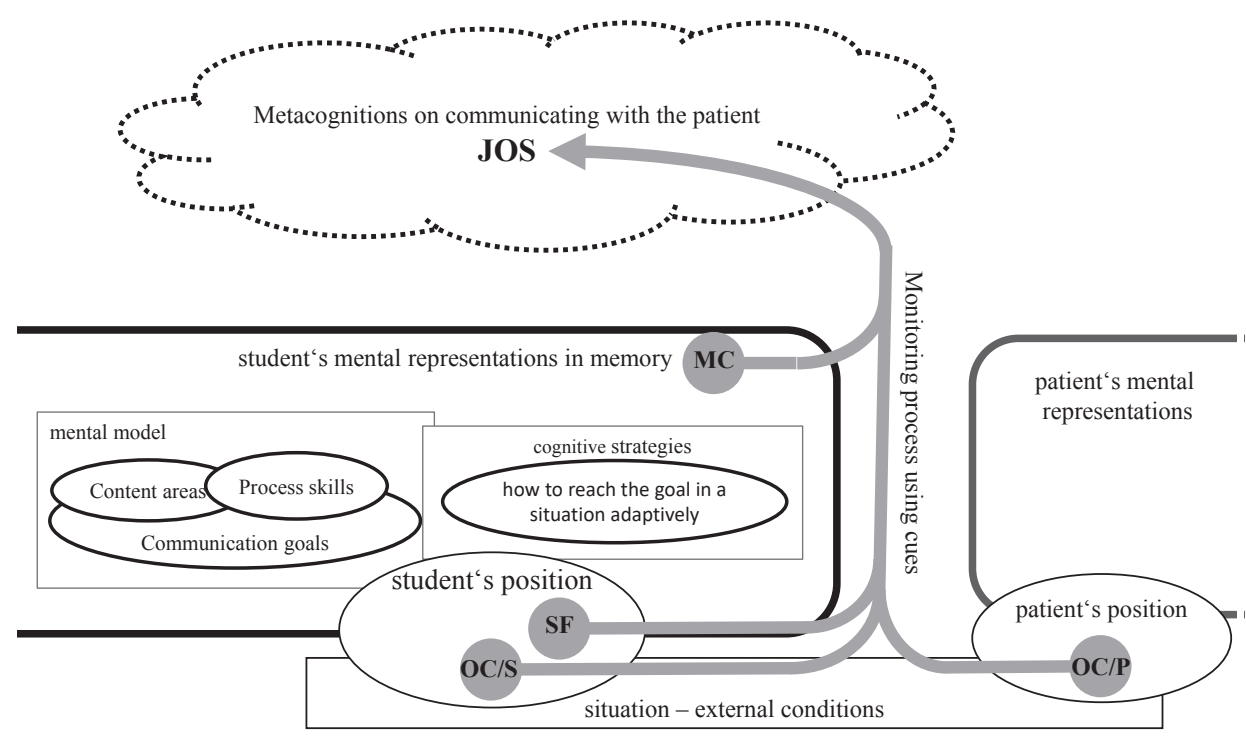

Figure 1: Visualization of students' monitoring process during patient interviews that lead up to Judgements of Satisfaction, based on the theoretical constructs of Koriat's cue-utilisation framework ${ }^{25}$ and Silverman et al.'s conversational model ${ }^{32,39} ; \mathrm{MC}=$ Memory cues, $\mathrm{OC} / \mathrm{S}=$ Observable cues student, $\mathrm{OC} / \mathrm{P}=$ Observable cues patient, $\mathrm{SF}=$ Subjective feelings, JOS = Judgement of satisfaction.

The first two types of cues concern the student's observations about the patient's behaviour or about his/her own behaviour during the patient interview (observable cues/patient $[\mathrm{OC} / \mathrm{P}]$ and observable cues/student $[\mathrm{OC} / \mathrm{S}])$. Third are the subjective feelings (SF) the interview may evoke in the student. Last, there are memory cues (MC) at play which are cues that originate in the student's memory. In the ideal situation that Figure 1 represents, student's memory is structured along principles of the conversational model. It contains both factual knowledge (mental model) about communication goals, process skills, content aspects and their interrelations, and procedural knowledge (cognitive strategies) on reaching the goal using process skills adaptively to cover relevant content aspects (depicted in Figure 1 as 'student's mental representations in memory'). In summary, student's monitoring process can involve the processing of OC/S, OC/P, SF and MC leading up to a self-judgement about the way the patient interview was conducted. 
In view of the aforesaid, we hypothesize that:

1. the principles of Koriat's cue-utilisation framework ${ }^{25}$ can be extrapolated to the realm of learning to interview patients. Students' metacognitive monitoring process during patient interviews relies on the cues OC, SF and MC and involves an integration of the cues $\mathrm{OC} / \mathrm{S}$ and $\mathrm{OC} / \mathrm{P}$ to form judgements of satisfaction (JOSs); and

2. students, in spelling out their judgements about their own performances during patient interviews, will link their appropriate or inappropriate use of process skills to a corresponding effect on the quality and quantity of the information gathered.

\section{Method}

We conducted a qualitative field study, having students complete a written assignment consisting of a metacognitive judgement task and some reflective prompts in their normal educational setting.

\section{Participants}

Our participants were second-year human medicine students of Medical University Vienna. As part of the program, students received specific communication skills trainings with simulated patients small group, 6 weeks, 90min/week; based on Silverman, Kurtz, and Draper, ${ }^{32}$ which were followed by an individual simulated patient practice appointment three months later. An OSCE-type Practical Clinical Clerkship Entry Examination (PCCEx) ended the training. The written assignment that constituted the core input of our study was part of this examination. Of the 680 students who were enrolled, 524 (77\%) consented to have their written assignments and PCCEx marks used for the study. As participation was voluntarily, we do not know why $23 \%$ opted out. We employed a stratified purposeful sampling technique ${ }^{33}$ to achieve a sample of 20 information-rich cases. Six parameters were combined to form three layers, so-called strata, optimizing the sample for hypothesis-testing (stratum 1) and controlling for possible confounders (stratum 2 and 3; Table 2).

Stratum one considered differences in case difficulty and students' learning ability as measured by the PCCEx, because students with higher metacognitive abilities have generally been shown to perform better compared to students with lower metacognitive abilities. ${ }^{23}$ The four ability levels combined with the five different patient roles led to a sample of at least 20 cases, which we sampled from 20 different training groups (Stratum 2) and controlled for actor and the sex of student and actor (Stratum 3). Students' age was not assessed, based on cohort's enrolment data the expected age range is between 20 and 25 years. The language of instruction was German. 


\section{Materials}

Simulated-patient encounter and video-recording. All students videorecorded their simulated patient practice encounter. Actors were advanced medical students who were trained to interpret five typical patient roles, relevant for clinical clerkships (Table 2). Students choose a role they liked to practice.

Table 2: Sampling parameter, their distribution for the sampling

\begin{tabular}{|c|c|}
\hline $\begin{array}{l}\text { Strata } \\
\text { Sampling parameter } \\
\text { available characteristics }\end{array}$ & $\begin{array}{l}\% \text { total } \\
\mathrm{n}=524\end{array}$ \\
\hline \multicolumn{2}{|l|}{ Stratum 1} \\
\hline \multicolumn{2}{|l|}{ patient role ${ }^{\mathrm{a}}$} \\
\hline Exploring pain (knee) — emergency outpatient department & $18 \%$ \\
\hline Embarrassed patient (pain when urinating) — urology outpatient department & $24 \%$ \\
\hline Chronic illness likely (diarrhoea) — internal medicine outpatient department & $29 \%$ \\
\hline Non-compliant patient (transfer to inpatient dep.) — cardiology department & $19 \%$ \\
\hline Worried patient $($ node $=$ cancer? $)-$ internal medicine outpatient department & $10 \%$ \\
\hline \multicolumn{2}{|l|}{ performance in PCCEx \& history-taking station ${ }^{\mathrm{b}}$} \\
\hline excellent performers & $29 \%$ \\
\hline good performers & $52 \%$ \\
\hline satisfactory performance & $12 \%$ \\
\hline sufficient/below sufficient ${ }^{c}$ & $7 \%$ \\
\hline \multicolumn{2}{|l|}{ Stratum 2} \\
\hline $\begin{array}{l}\text { Communication class }- \text { training groups } \\
68 \text { training groups }(\sim 10 \text { students/group }) / 40 \text { teachers }^{d}\end{array}$ & -- \\
\hline \multicolumn{2}{|l|}{ Stratum 3} \\
\hline \multicolumn{2}{|l|}{ Sex students } \\
\hline Male & $56 \%$ \\
\hline Female & $44 \%$ \\
\hline \multicolumn{2}{|l|}{ Sex simulated patient (SP); 14 male/15 female actors ${ }^{\mathrm{e}}$} \\
\hline encounters with male SP & $55 \%$ \\
\hline encounters with female SP & $45 \%$ \\
\hline Realizable: $6 \mathrm{~m} / \mathrm{f}, 5 \mathrm{f} / \mathrm{m} ; 5 \mathrm{f} / \mathrm{f} ; 4 \mathrm{~m} / \mathrm{m}$ & \\
\hline
\end{tabular}

Notes: PCCEx = OSCE-type practical clinical clerkship entry exam,

${ }^{a} \mathrm{n}$ of patient roles depends on the availability of actors on the training day, actors play more than one case but not all cases, this could not be controlled due to the complexity of students' and actors' schedule.

${ }^{b}$ performance in history-taking station had to be combined with the PCCEEx performance to improve reliability, to keep validity of the sampling cases with little variance between and history-taking station were preferred.

${ }^{c}$ defined by a modified Angoff-standard-setting procedure

d $4 \mathrm{~h}$ standardized teacher training to ensure teaching quality between the groups, 1-3 groups per teacher

${ }^{\mathrm{e}} 3 \mathrm{~h}+3 \mathrm{~h}$ standardized patient training, mean number of role play $=17, \mathrm{~s}=11$ 
Metacognitive judgement task and written assignment. Students were instructed to review their video and select relevant scenes about which they clearly felt satisfied or dissatisfied with respect to their performance. They then answered the following question: "How satisfied are you with the selected scene?" (not satisfied/very satisfied). Finally, they were invited to elaborate on their JOS in writing ('Briefly describe what is happening in the selected scene' and 'Explain why you are satisfied/not satisfied with this scene').

\section{Procedure}

Before video-recording the encounter, students received a form with basic information about the study and a consent statement. They then completed the written assignment which was later discussed in a PCCEx station. It was emphasized that the focus of the assignment was their ability to analyze strengths and weaknesses, similar to small group practice.

\section{Analysis}

We performed a directed content analysis ${ }^{34}$ by classifying text representing similar meaning into categories. The key concept behind this approach is that existing theory guides the initial coding of categories, also called deductive category application, 35 while allowing for the revision of coding categories and their definitions in reaction to the text. Hence, for validating or conceptually extending a theory or theoretical framework like the cue-utilisation framework, it can be a powerful tool. We used Atlas. $\mathrm{ti}^{36}$ to manage the category application and to derive the category's frequency counts.

Unitizing. Students' elaborations on their judgements, hence not the patient interviews themselves, were transcribed and organized into propositional units, ${ }^{37}$ that were structured as follows: 'I am satisfied/not satisfied with $X$ because I didlobservedl perceive $Y$, which I know/believe to be Z'.

Deductive category application. From our integrated model represented in Figure 1 we derived the two coding dimensions 'types of cues used' and 'themes mentioned in elaboration'. Their reliability was checked formatively ${ }^{35}$ by constantly comparing the assigned statements.

Types of cues used. This dimension was inspired by Koriat's cue-utilisation framework, ${ }^{25}$ while Silverman et al.'s conversational model ${ }^{32}$ served to further embellish its categories (Table 1, right column gives a specification).

Themes mentioned in elaboration. This dimension built entirely on the conversational model. We derived the two nominal categories 'content aspects' (CA) and 'process skills' (PS) and divided them into three and eight subcategories, respectively. Within the CA category we distinguished the subcategories 'biomedical perspective (CA/BP)', 'patient's perspective (CA/PP)', and 'background information (CA/BI)' defined according to Silverman, Kurtz, Draper, ${ }^{32, p .19}$. For the PS subcategories we 
modified Silverman et al.'s definition 32, p.20-23,p.28 to reduce ambiguity and enhance coder consistency: 'questioning style (PS/QS)', 'attentive perception (PS/AP)', 'facilitative response (PS/FR)', 'picking up cues (PS/PuC)', 'providing structure (PS/PStr)' as well as 'building the relationship-(non-)verbal behaviour/expressing attitude towards patient (PS/nVB-att.) and 'building the relationship-appropriate use of language (PS/AuL)'. (A detailed description of modification and examples can be obtained from the first author).

Quantitative steps of analysis. To enhance our qualitative interpretation, we counted frequencies of code occurrence and pairwise co-occurrence (c-index) of theoretically relevant categories. The $c$-index, ${ }^{36}$ rooted in quantitative content analysis normalises the co-occurrence frequencies $(\mathrm{c}-\mathrm{index}=\mathrm{n} 12 /(\mathrm{n} 1+\mathrm{n} 2)-\mathrm{n} 12 ; \mathrm{n} 12=c o$ occurrence frequency of two codes $c 1$ and $c 2, n 1$ and $n 2$ being their respective occurrence frequency). It varies between 0 and 1 , where 0 indicates that the two codes never cooccur and 1 that they do so in all instances. We use the following, arbitrary set, levels of co-occurrence: low degree ( $c<0.25$; meaning both codes are used in less than $25 \%$ of the cases), medium degree ( $c \geq 0.25$ and $<0.75)$, and high degree $(c \geq 0.75)$.

\section{Results}

\section{Unitizing: Identifying Expressions}

Principal investigator MWM and a German-speaking research assistant unitized the material. The number of scenes selected to form a JOS varied between students (mean $=3.3, \mathrm{SD}=1.2, \min =1, \max =5)$, as did the number of expressions (mean $1.9, \mathrm{SD}=1.2, \min =1, \max =7$ ) they needed to elaborate each JOS. Twenty students provided a total of $67 \mathrm{JOSs}$, with 133 expressions. Scenes students were dissatisfied with (61\%) generally outnumbered those they were satisfied with (39\%). This also holds for the individual student as shown by the low mean ratio of positive judgements to total number of judgements (JOS ${ }_{\text {ratio }}$ per student) (Table 3).

\section{Deductive Category Application}

MWM and AdB coded a subset of 15 randomly chosen statements jointly to test the initial definition of nominal categories and subcategories. The remaining statements were coded by MWM and a research assistant. 
Table 3: Unitizing - Descriptive results

\begin{tabular}{|c|c|c|c|c|}
\hline & Mean & SD & $\mathrm{N}$ & $\%$ unit \\
\hline Student as unit & -- & -- & 20 & -- \\
\hline Number of JOSs per student & 3.3 & 1.2 & -- & -- \\
\hline $\begin{array}{l}\mathrm{JOS}_{\text {ratio }} \text { per student } \\
\left.=\mathrm{JOS}_{\text {satisfied }} / \mathrm{JOS}_{\text {satisfied }}+\mathrm{JOS}_{\text {not satisfied }}\right)\end{array}$ & 0.38 & 0.26 & -- & -- \\
\hline JOS as unit & -- & -- & 67 & -- \\
\hline $\mathrm{JOS}_{\text {satisfied }}$ & -- & -- & 26 & $39 \%$ \\
\hline $\mathrm{JOS}_{\text {not satisfied }}$ & -- & - & 41 & $61 \%$ \\
\hline Number of expressions ${ }^{a}$ per JOS & 1.9 & 1.2 & -- & -- \\
\hline Duration of scenes selected for JOS (min:sec) & $1: 25$ & $1: 41$ & 67 & -- \\
\hline Expression as unit & -- & -- & 133 & -- \\
\hline
\end{tabular}

Notes: JOS = Judgment of satisfaction

${ }^{a}$ Expressions that could be arranged into propositional units of the type: 'I am satisfied/not satisfied with X because I did/observed/perceive Y, which I know/believe to be Z'.

\section{Types of Cues Used (Hypothesis 1)}

Observable cues, subjective feelings, memory cues. The OC/S, OC/P, MC and SF codes were easy to assign. A typical example of an OC/S, in which the student elaborates on what he or she did, is the following: Ask about partner, Contraception, Point out STD-I stuttered too much, I could not find the appropriate words. [...].' (P8). Quite different is the next example of an OC/P code, in which the student reflects on what the patient said: 'The patient reports burning pain when urinating, started anew two weeks ago, [...].' (P12). Some expressions required the joint assignment of OC/P and $\mathrm{OC} / \mathrm{S}$ codes, for instance in the following example where the student elaborates on what the patient said and what he or she did in response: 'Question about urine and stool: After receiving "normal" for an answer I asked the suggestive questions "brown?", "not often?" (P43). The expressions we labelled as SF-cues typically included adjectives referring to the quality, quantity or the suitability of an action in the scene: 'I asked the patient if her parents were still alive. The question was not phrased well --> too straightforward, too direct' (P32). Finally, a typical example of an MC would read: 'Suggestive questions cause many patients to agree and to stop telling other details even if they wanted to tell something'(P28).

Students tended to base their judgements more frequently on observations of their own behaviour (in 57\% of the expressions) rather than the patient's (in $31 \%$ of the expressions). We expected a theoretically relevant co-occurrence of the cues OC/S and $\mathrm{OC} / \mathrm{P}$, as this is essential to integrate behavioural information of both interactors. Surprisingly, we found that these cues were used jointly in only $21(16 \%)$ of the expressions, while the c-index of 0.22 signalled only a low to medium degree of cooccurrence. This also means that hypothesis 1 could not be fully confirmed. As this joint use of OC/S and OC/P cues is important for effective patient communication, we 
suggest that this topic be subjected to further scrutiny. In regards to the categories SF and MC, these were used in $61(46 \%)$ and 35 (26\%) expressions, respectively (Table 4).

Table 4: Observable cues, subjective feelings, memory cues and proxy judgements: Frequencies, theoretically relevant co-occurrence

\begin{tabular}{|c|c|c|c|}
\hline $\begin{array}{l}\text { category } \\
\text { subcategory }\end{array}$ & $\mathrm{n}$ & $\%$ total $n=133$ & c-index \\
\hline Observable cues (OC) & 96 & $72 \%$ & -- \\
\hline Student-emitted (OC/S) & 75 & $57 \%$ & -- \\
\hline Patient-emitted (OC/P) & 41 & $31 \%$ & -- \\
\hline co-occurrence OC/S \& OC/P & 21 & $16 \%$ & 0.22 \\
\hline OC/S unique & 55 & $42 \%$ & -- \\
\hline $\mathrm{OC} / \mathrm{P}$ unique & 20 & $15 \%$ & -- \\
\hline Subjective feelings (FS) & 61 & $46 \%$ & -- \\
\hline Memory cues (MC) & 35 & $26 \%$ & -- \\
\hline Proxy judgements (PJ) & 72 & $54 \%$ & -- \\
\hline Summative behaviour (PJ/SUB) & 39 & $29 \%$ & \\
\hline Forgot to ask (PJ/FTA) & 24 & $18 \%$ & -- \\
\hline Interpreting patient's experience or behaviour (PJ/IPE) & 17 & $13 \%$ & -- \\
\hline
\end{tabular}

Notes: $\mathrm{OC}=$ Observable cues, $\mathrm{OC} / \mathrm{S}=$ Student-emitted observable cues, $\mathrm{OC} / \mathrm{P}=$ Patient-emitted observable cues, OC/S \& OC/P = co-occurrence of observable cues emitted by student and observable cues emitted by patient, OS/S unique = occurrence of observable cue emitted by student without co-occurrence of other observable cues, OS/P unique = occurrence of observable cue emitted by patient without cooccurrence of other observable cues, $\mathrm{SF}=$ Subjective feelings, $\mathrm{MC}=$ Memory cues, $\mathrm{PJ}=$ Proxy judgments, SUB $=$ Summative behaviour, FTA $=$ Forgot to ask, IPE = Interpreting patient's experience or behaviour

Revision of categories in reaction to the text. The joint reading and coding process revealed that the Koriat-inspired array of cues with which we started the analysis failed to represent important expression segments. What these segments shared was that they integrated $\mathrm{MC}$ with situationally available information to form a judgement, which, in turn, served as cue that led up to a JOS. Unlike subjective feelings that are independent of content, these judgements were content-specific. We therefore coined them 'proxy judgements (PJ)' and added them to our cue repertoire. A refinement of this new category led to the inclusion of three conceptually relevant subcategories, being 'summative behaviour (PJ/SUB)', 'forgot to ask something (PJ/FTA)' and 'interpreting patient's experience (PJ/IPE)' which receive further clarification in the next paragraphs.

The first proxy judgement, 'summative behaviour (PJ/SUB)', manifests itself when a student uses attributes or adjectives to describe apparently observed behaviour. 
For instance in the sentence '... the questions were rather general ... 'the attribute 'general' qualifies the 'questions'. As the student cannot determine whether a question is 'general' purely based on observations, he or she must draw from previous knowledge, in this example from the skills acquired through communication skills training to distinguish between open-ended and closed-ended questions, and between general and specific questions.

Second, we assigned the code 'forgot to ask something (FTA)' when students reported being dissatisfied because they forgot to ask something. Since you cannot actually observe the absence of a question, such statements could not be classified as OC, which we would have done in the reverse case - if a student reported having asked a question. Hence, again, prior knowledge, in this case about what had to be asked, needs to be activated, although none of these statements included explicit elaborations on what exactly should have been asked. Finally, the proxy judgement 'Interpreting patient's experience (IPE)' was coded when students elaborated on how they interpreted the patient's experience in the situation, for example: 'patient is in an unfavorable and difficult situation'.

The finding that 72 (54\%) of all expressions contained proxy judgements, reinforces our expansions of Koriat's cue repertoire (Table 4). We found proof that students indeed employ the specified cues OC/S, OC/P, SF and MC, however, given the complexity of the domain, we have also found that there are at least three additional cues, the so called proxy-judgements (PJ), at play.

\section{Themes Mentioned in Elaboration (Hypothesis 2)}

Content aspects and process skills. Examining what themes students focus on when elaborating on their JOSs, we experienced no difficulty in pinpointing content aspects (CA). A typical example, in which the student focuses on his/her neglect to discuss relevant content (in this case: background information), is the following: I am 'not satisfied' with this sequence, because ... 'doing an internal summary on Personal and Social History, I realized I did not talk about sexually transmitted diseases and his ex-girlfriend'. (P9) A typical example of a focus on process skills (PS), by contrast, would read (in this case: providing structure to the consultation): I am 'not satisfied' with this sequence, because ... 'taking past medical history, family history and review of systems I did not use good transition statements, also I lost track and paused between two parts. (P54) When assigned PS together with CA codes, themes were interlinked by words like 'because'. For instance: I am 'very satisfied' with this sequence, because ... I asked the patient about his current complaints, why he is in the ambulance today, about pain, quality and when they began (...) Doing this I learnt a lot about the patient's current problem, because I kept asking and kept waiting and asking' which I know/believe: ... 'in order to motivate the patient to talk. (P57; expression 1) 
Table 5: Themes mentioned in elaboration: Frequencies, theoretically relevant co-occurrence

\begin{tabular}{|c|c|c|c|}
\hline Category & $\mathrm{n}$ & $\%$ total $n=133$ & c-index \\
\hline \multicolumn{4}{|l|}{ Subcategory } \\
\hline Content area (CA) & 58 & $44 \%$ & -- \\
\hline Biomedical perspective (CA/BP) & 13 & $10 \%$ & -- \\
\hline Patient's perspective (CA/PP) & 4 & $3 \%$ & -- \\
\hline Background information (CA/BI) & 42 & $32 \%$ & -- \\
\hline Process skills (PS) & 91 & $68 \%$ & -- \\
\hline Questioning style (PS/QS) & 19 & $14 \%$ & -- \\
\hline Attentive perception (PS/AP) & 19 & $14 \%$ & -- \\
\hline Picking up cues (PS/PuC) & 10 & $8 \%$ & -- \\
\hline Facilitative response (PS/FR) & 9 & $7 \%$ & -- \\
\hline Building the relationship (PS/BR) & & & -- \\
\hline (non-)verbal behaviour (PS/BR/nVB) & 20 & $15 \%$ & -- \\
\hline Appropriate use of language (PS/BR/AuL) & 11 & $8 \%$ & -- \\
\hline Providing structure (PS/PStr) & 13 & $10 \%$ & -- \\
\hline Co-occurrence (CA \& PS) & 16 & $12 \%$ & 0.12 \\
\hline CA unique & 42 & $32 \%$ & -- \\
\hline PS unique & 75 & $56 \%$ & -- \\
\hline co-occurrence (CA \& PS) - Topics & & -- & -- \\
\hline PS/QS à information's quality & 1 & -- & -- \\
\hline PS/AP à information's quality & 5 & -- & -- \\
\hline PS/AP à communication's quality & 3 & -- & -- \\
\hline $\mathrm{PS} / \mathrm{PuC}$ à information's quality & 1 & -- & -- \\
\hline PS/PuC à communication's quality & 3 & -- & -- \\
\hline PS/FR à information's quality & 1 & -- & -- \\
\hline PS/BR à information's quality & 2 & -- & -- \\
\hline PS/PStr à communication's quality & 2 & -- & -- \\
\hline
\end{tabular}

Notes: $\mathrm{CA}=$ Content area, $\mathrm{BP}=$ Biomedical perspective, $\mathrm{PP}=$ Patient's perspective, $\mathrm{BI}=$ Background information,

$\mathrm{QS}=$ Questioning style, $\mathrm{AP}=$ Attentive perception, $\mathrm{PuC}=$ Picking up cues, $\mathrm{FR}=$ Facilitative response, $\mathrm{BR}=$ Building the relationship, $\mathrm{nVB}=($ non-) verbal behaviour, AuL, Appropriate use of language, PStr = Providing structure 
Regarding frequencies, we found these to be high for both CA (44\%) and PS (68\%). The content aspects were more often related to background information (CA/BI) than to biomedical perspective (CA/BP) while they hardly ever concerned the patient's perspective (CA/PP). The counts for co-occurrence of PS with CA, however, were low, with only $12 \%$ of the expressions connecting the application of process skills with the quality or quantity of the content aspects. The c-index of 0.12 also indicates a low degree of co-occurrence. The process skills students reflected on most often were 'questioning style' (14\%), 'attentive perception' (14\%) and 'relationship-building based on verbal or nonverbal behaviour' (15\%) (Table 5).

Although we had no difficulty in applying the principles of Silverman's conversational model to our analysis, to the extent that we could indeed group students' judgements along the themes 'content aspects' and 'process skills', hypothesis 2 could not be fully confirmed.

Three types ofJOSs. In retrospect, we can distinguish three types of JOSs which differ in focus: judgements that focus 1) on content (JOS-type-a: information quality/ quantity); 2) on process skills (JOS-type-b: communication technique quality); and 3) on the appropriateness of the process skill utilized in view of the goal to be attained (JOStype-c: situational appropriateness). These JOSs-types also differ regarding the numbers of satisfaction/dissatisfaction judgements and numbers of high/poor performers in the PCCEx (Table 6). Thus, we believe that further application of this distinction may facilitate future research into the essentials of effective patient communication. A summary of JOS-types and examples are displayed in Table 7.

Table 6: Contingency table presenting the counts of satisfaction/dissatisfaction judgements and of high/ poor performers in the PCCEx for each JOS-type (c-index in parentheses)

\begin{tabular}{cccc}
\hline & \multicolumn{3}{c}{ Themes mentioned in elaboration } \\
\cline { 2 - 4 } & Content aspects & Process skills & $\begin{array}{c}\text { Content aspects \& } \\
\text { Process skills }\end{array}$ \\
\hline $\begin{array}{c}\text { Expressions from satisfaction/dissatisfaction } \\
\text { satisfaction }\end{array}$ & $16(0.38)$ & $27(0.36)$ & $9(0.56)$ \\
dissatisfaction & $26(0.62)$ & $48(0.64)$ & $7(0.44)$ \\
Expressions from high/poor performers & & & $15(0.93)$ \\
high performers & $20(0.47)$ & $53(0.71)$ & 1 (n.a.) \\
\hline poor performers & $22(0.45)$ & $22(0.29)$ & \\
\hline
\end{tabular}

Notes: high performers = students with good to excellent performance in the practical clinical clerkship entry exam (PCCEx); poor performers = students with insufficient to satisfactory performance in PCCEx., Italicized values represent the c-indexes exceeding the arbitrarily set value of $c>0.25$. 
Table 7: Three types of Judgments of satisfaction (JOS), definition, relation to external criteria, examples

JOS-type**
(a) completeness (or the lack thereof) of
covered content
1) no relation to PCCEx
2) more dissatisfaction than satisfaction
expressions
(b) quality of performing a process skill
1) more often provided by PCCEx high performers
2) more dissatisfaction than satisfaction expressions Example

(P58, E1): very satisfied; Family history, checking if there are further illnesses common in her family. After she had answered about her father's heart attack I ask [...]. (P9, E2): not satisfied; Doing an internal summary on Family History I have not talked about sexually transmitted diseases and former sexual partners. 1

(P22, E1): very satisfied; I am exploring problems in daily life, support, significant others, stress; good, that my questions where rather general (talkative patient).

(P13, E1): not satisfied; Patient talks about [...] "uh regarding your [...], you feel good about [...]"; do not think aloud, do not say "you feel good about" - suggestive statement.

(c) appropriateness of process skill to reach goal

(P28, E1) very satisfied; The patient tells me about [...]. I 1) nearly all expressions provided by PCCEx high performers

2) no systematic relation with satisfaction/dissatisfaction let (her) talk as she wishes and I listen attentively [...] she is telling a lot and long à thus patient experiences that her fears are heard here.

(P12, E1) not satisfied; The patient reports [...]. [...] explored localization not precisely enough, doubt concerning this runs through the rest of the encounter, I probably was too self-conscious because of the "intimate localization --> not professional

Notes: ** Cells contain the following information: 1) Relation with level of performance in the PCCEx; (Practical clinical clerkship entry exam; high performers = students with good to excellent performance; poor performers = insufficient to satisfactory performers: 2) Relation with satisfaction/dissatisfaction judgements

\section{Discussion}

This study adopted a cognitive-psychological approach to students' problems in transferring communication skills from medical school's simulation training to clinical practice by focusing on the metacognitive processes involved. We adapted Koriat's cueutilisation framework of metacognitive monitoring ${ }^{25,38}$ to analyze how students monitor the process of learning to interview patients. Our study confirmed that students do indeed employ the cues defined by the cue-utilisation framework to form JOSs when monitoring their history-taking performance. Hence, we found the cue-utilisation framework to be a useful tool for analyzing metacognitive processes involved in historytaking.

Yet, we also found that in order to fully capture the complexity of patient communication, the framework required expansion. Therefore, we introduced three new domain-specific cues, coined proxy judgements (PJ). Whilst one of these focused on the goal to obtain the desired information from the patient (PJ/FTA), another was particularly geared towards interpreting the patient's experience and behaviour (PJ/IPE). 
A third cue evolved when students used adjectives and adverbs to summarize behaviour they felt they observed (PJ/SUB). This is striking, as accepted rules for providing student feedback discourage the use of summative-behaviour-descriptors because specific descriptive statements comparable to the cue-utilisation framework's OC are easier to translate into behavioural changes. ${ }^{39}$ Our findings, however, suggest that a summative behaviour proxy judgement, which arises effortlessly in the student's mind, may have a powerful indicator function. It signals students a need to explore behaviour in more detail. However, this explanation requires further testing.

Our findings also demonstrated that the JOSs students form when monitoring their history-taking performance can be three in kind, depending on the theme or themes they focus on. In the case of the first two types, tagged as 'JOS-type-a' and 'JOS-type-b', judgements were based exclusively on either content (a) or the quality of the communication technique (b). When forming an a-type JOS, students went at lengths to check all items of the content list dictated by the course material, leaving them dissatisfied if certain topics on the checklist could not be covered. Evidently, at this early stage of training, students still lacked the skills to tailor their communication strategies to clinical reasoning, being unable to judge which items were relevant or not and being overly concerned with coverage of content instead. When forming a b-type JOS students were committed to applying the communication techniques in the exact way their teachers had taught them. Being able to harness and execute these process skills gave cause for satisfaction.

Typically, neither a-type nor b-type JOSs included reflections on how student's communication strategy affected the patient and his/her narrative. The limited number of judgements that did consider this relationship belong to the JOSs of type c: By balancing the appropriateness of the communication technique employed in view of the goal to gather the information needed for a correct initial diagnosis, students exhibited behaviour that teachers wish to encourage in students. ${ }^{32}$ The finding that such judgements are rare at this stage of education finds resonance in previous medical education research. A qualitative study on the acquisition of consultation skills, for instance, revealed that, when judging the quality of observed and performed consultations during clerkships, only a few students considered how their communication strategies affected the patient. The study concluded that integrating good patient-communication with clinical reasoning is a skill medical students find extremely difficult to master. ${ }^{14}$

At face value our results may seem to replicate previous findings emphasizing that students tend to specifically identify scenes they are dissatisfied with..$^{40}$ When considering the distribution of positive and negative judgements for each JOS type, however, our findings shed new light on this matter. While judgements of types $\mathrm{a}$ and $\mathrm{b}$ were indeed predominantly negative (= dissatisfied), those of type c, however, appeared to be more evenly distributed between positive and negative judgements. On further scrutiny of the process skills students were dissatisfied with, we moreover gained the striking insight 
that students at this educational stage lack sufficient verbal repertoire to implement the process skills. This was reflected in the high number of students' utterances about using appropriate language (PS/BR/AuL). Our study therefore provides empirical evidence that at least some students need additional help in developing a verbal repertoire. Discussing our results with our teachers, actors and some students, they remembered situations where actors interviewed by students who lacked adequate vocabulary even made jokes, such as 'learn your text' or 'you lack verbal repertoire for this improvisation'. They also observed that some students, to remedy their shortcomings, began listening closely to other students' role play in order to capture good verbal expressions and left the course with a list of questions or phrases for all sorts of situations.

\section{Limitations}

Some limitations to this study are worth noting. First, to smooth instructions and to prevent misunderstandings as to how the assignment should be performed, we decided to work with a dichotomous judgement scale. During the analysis we found this to be a disadvantage, because we could no longer distinguish the particular weights students attached to the selected scenes and their respective judgements. Studies on similar metacognitive assessments, such as judgements of diagnostic certainty, employ a wider scale. ${ }^{41}$ We therefore suggest that future studies on JOSs about performance follow their example.

Next, partly due to the pilot character of the study and the complexity of the domain, we did not set students' metacognitive judgements against an external standard in order to determine their accuracy. Hence, although our study brought to light which cues students employed, we cannot make any predictions about their usefulness. Future studies will need to address this and compare students' judgements to benchmark judgements. This is all the more important since students' self-judgement capabilities play a key role in facilitating the delivery of feedback by faculty. ${ }^{30,31}$ An experimental study by Cavalcanti, Sibbald ${ }^{41}$ into the relation between diagnostic certainty and diagnostic accuracy during physical examination effectively deployed simulators as standardized stimulus material. We may well derive inspiration from this example a possible modification for instance, would be to use a well-defined set of pre-rated stimulus videos instead of students' own videos to investigate their judgement behaviour.

There is also no objective measure to determine whether the sequences selected by the students to derive a JOS are relevant sequences as compared to an external standard. Students may have felt obliged to select sequences to elaborate on them resulting in JOS-type-a and JOS-type-b, likely easier to report on than the JOS-type-c. This assumption is supported by the small number of JOS-type-c. But because JOStype-c accumulate among some high-performance students, whom we expect to have performed well when training history-taking, we consider this explanation less likely. The question if those high performing students have already progressed further in their 
skill acquisition because of a difference in general ability, or because they had more or a different sort of teaching, can currently not be answered.

\section{Conclusion}

When progressing from novice to expert in communicating with patients, medical students face two challenges. First, they come to medical school with their own style of communicating. Experiencing the need for modifying or expanding it means to change secure routines and is thus a source of uncertainty. ${ }^{6}$ Second, communicating always requires preparing for something new and/or surprising. Using communication techniques will only enhance the probability that the encounter goes well and that the taken history informs the clinical reasoning. However, like in performing arts, there is no guarantee it really turns out well. Using the cue-utilisation framework for analyzing students' metacognitions facing these challenges in history-taking enabled us to describe students' reflections on their learning of history-taking. Thus we expand the focus of systems for describing reflections suggested elsewhere, ${ }^{40}$ by allowing detailed analysis of the monitoring process based on an experimentally proven judgement model. A main finding is that students' metacognitive judgements focus on two communication-specific themes, being the quality and appropriateness of implemented communication skills (JOS-type-b) and the effect good communication has on the patient and on the quality of the information gathered (JOS-type-c). In studies on consultation skills acquisition, the students relating their performance to what effect their behaviour has on the patients seemed to be the ones least afflicted by the shift between training and clinical setting. ${ }^{14}$ Thus, in order to foster transfer from training to clinical setting, future studies should focus on explaining why students expressed only few JOS-type-c judgements.

Our study also reveals students' concern about covering content as specified by a checklist, rather than reflecting about covering content meeting medical needs, which could potentially inhibit the further development of history-taking skills. Discussing how to change that should be the subject of future studies, as having students practice incorporating good patient communication with medical thinking on very easy problems has been shown to be considered important for identity formation. ${ }^{14}$ We found first hints that high-performance students are better able to integrate patient-emitted with student-emitted cues while focusing on the goal of history-taking. Thus, the modified cue-utilisation framework can be used in the future to describe more closely how highperforming students and low-performing students differ in generating JOS when taking new patients' history.

We also hope our findings on the usefulness of the cue-utilisation framework for analyzing medical students' cognitive processes when practicing a complex practical skill will stimulate further research on how students arrive at metacognitive judgements, like satisfaction or confidence judgements regarding their mastering of complex skills. Such results would be valuable for all educators responsible for developing skills training. 


\section{Acknowledgments}

Our thanks go to Tim Dornan, who took the effort to discuss suitable steps for the qualitative analysis with us, to Jan van Dalen who provided an early draft of this work with useful ideas, to Angelique van den Heuvel for magically transforming our German/Dutch-English into English-English and to Michael Schmidts, Martin Lischka and Siegfried Meryn for supporting this study. 


\section{References}

1. Hampton JR, Harrison MJG, Mitchell JRA, Prichard JS, Seymour C. Relative contributions of history-taking, physical-examination, and laboratory investigations to diagnosis and management of medical outpatients. Br Med J. 1975;2(5969):486-489.

2. Peterson MC, Holbrook JH, Vonhales D, Smith NL, Staker LV. Contributions of the history, physical-examination, and laboratory investigation making in medical diagnoses. West $J$ Med. 1992;156(2):163-165.

3. Chen RC, Clark JA, Manola J, Talcott JA. Treatment 'mismatch' in early prostate cancer-Do treatment choices take patient quality of life into account? Cancer. 2008;112(1):61-68.

4. Maguire P, Pitceathly C. Key communication skills and how to acquire them. Br Med J. September 2002;325:697.

5. Zolnierek KBH, DiMatteo MR. Physician Communication and Patient Adherence to Treatment A Meta-Analysis. Med Care. 2009;47(8):826-834.

6. Ericsson KA. Deliberate Practice and Acquisition of Expert Performance: A General Overview. Acad Emerg Med. 2008;15(11):988-994.

7. Yedidia MJ, Gillespie CC, Kachur E, et al. Effect of communications training on medical student performance. JAMA. 2003;290(9):1157-1165.

8. Wouda JC, van de Wiel HBM. Education in patient-physician communication: How to improve effectiveness? Patient Educ Couns. 2013;90(1):46-53.

9. Bombeke K, Symons L, Vermeire E, et al. Patient-centredness from education to practice: The 'lived' impact of communication skills training. Med Teach. 2012;34(5):E338-E348.

10. Rosenbaum ME, Axelson R. Curricular disconnects in learning communication skills: What and how students learn about communication during clinical clerkships. Patient Educ Couns. 2013;91(1):85-90.

11. Hook KM, Pfeiffer CA. Impact of a new curriculum on medical students' interpersonal and interviewing skills. Med Educ. 2007;41(2):154-159.

12. Williams C, Cantillon P, Cochrane M. The doctor-patient relationship: from undergraduate assumptions to pre-registration reality. Med Educ. 2001;35(8):743-747.

13. Brown J. Transferring Clinical Communication Skills From the Classroom to the Clinical Environment: Perceptions of a Group of Medical Students in the United Kingdom. Acad Med. 2010;85(6):1052-1059.

14. Aper L, Veldhuijzen W, Dornan T, et al. "Should I prioritize medical problem solving or attentive listening?": The dilemmas and challenges that medical students experience when learning to conduct consultations. Patient Educ Couns. 2015;98(1):77-84.

15. van Merriënboer JJG. Training complex cognitive skills. Englewood Cliffs, NJ: Educational Technology Publications; 1997.

16. Flavell JH. Metacognition and Cognitive Monitoring. A new area of Cognitive-Developmental Inquiry. Am Psychol. 1979;34(10):906-911.

17. Nelson TO, Narens L. Metamemory: A theoretical framework and new findings. In: Bower GH, 
ed. The psychology of learning and motivation. Vol 26. New York: Academic Press; 1990:125-173.

18. Schön DA. The Reflective Practitioner. How Professionals think in Action. Aldershot, GB: Ashgate; 1983.

19. Dunlosky J, Thiede KW. Four cornerstones of calibration research: Why understanding students' judgements can improve their achievement. Learn Instr. April 2013;24:58-61.

20. Koriat A. The relationships between monitoring, regulation and performance. Learn Instr. 2012;22(4):296-298.

21. Thiede KW, Anderson MCM, Therriault D. Accuracy of metacognitive monitoring affects learning of texts. J Educ Psychol. 2003;95(1):66-73.

22. DeBruin A, Thiede KW, Camp G, Redford J. Generating keywords improves metacomprehension and self-regulation in elementary and middle school children.J Exp Child Psychol. 2011;109(3):294310.

23. Dunlosky J, Rawson KA. Overconfidence produces underachievement: Inaccurate self evaluations undermine students' learning and retention. Learn Instr. 2012;22(4):271-280.

24. van Loon $\mathrm{MH}$, de Bruin $\mathrm{ABH}$, van Gog T, van Merriënboer JJG. Activation of inaccurate prior knowledge affects primary-school students' metacognitive judgements and calibration. Learn Instr. April 2013;24:15-25.

25. Koriat A. Monitoring one's own knowledge during study: A cue-utilization approach to judgments of learning. J Exp Psychol Gen. 1997;126(4):349-370.

26. Dunlosky J, Rawson KA. Why does rereading improve metacomprehension accuracy? Evaluating the levels-of-disruption hypothesis for the rereading effect. Discl Process. 2005;40(1):37-55.

27. Thiede KW, Dunlosky J, Griffin TD, Wiley J. Understanding the delayed-keyword effect on metacomprehension accuracy. J Exp Psychol-Learn Mem Cogn. 2005;31(6):1267-1280.

28. Martin D, Regehr G, Hodges B, McNaughton N. Using Videotaped Benchmarks to Improve the Self-assessment Ability of Family Practice Residents. Acad Med. 1998;73(11):1201-1206.

29. Hawkins SC, Osborne A, Schofield SJ, Pournaras DJ, Chester JF. Improving the accuracy of self-assessment of practical clinical skills using video feedback - The importance of including benchmarks. Med Teach. 2012;34(4):279-284.

30. Kogan JR, Conforti LN, Bernabeo EC, Durning SJ, Hauer KE, Holmboe ES. Faculty staff perceptions of feedback to residents after direct observation of clinical skills. Med Educ. 2012;46(2):201-215.

31. Eva KW, Armson H, Holmboe E, et al. Factors influencing responsiveness to feedback: on the interplay between fear, confidence, and reasoning processes. Adv Health Sci Educ Theory Pract. 2012;17(1):15-26.

32. Silverman J, Kurtz S, Draper J. Skills for Communicating with Patients. Oxford: Radcliffe; 2005.

33. Sandelowski M. Combining qualitative and quantitative sampling, data collection, and analysis techniques in mixed-method studies. Res Nurs Health. 2000;23:246-255.

34. Hsieh H-F, Shannon SE. Three approaches to qualitative content analysis. Qual Health Res. 2005;15(9):1277-1288.

35. Mayring P. Qualitative Content Analysis. FOS. 2000; 1(2):20-June200; http://www.qualitative- 
research.net/index.php/fqs/article/view/1089/2385. Accessed 21.10.2014, 2014.

36. atlas.ti7 Qualitative Data Analysis [computer program]. Berlin (Germany): ATLAS.ti GmbH; 1993-2014.

37. Krippendorf K. Content Analysis. An Introduction to Its Methodology. Thousand Oaks, CA: SAGE 2004.

38. Koriat A. The self-consistency model of subjective confidence. Psychol Review. 2012;119(1):80-113.

39. Kurtz S, Silverman D, Draper J. Teaching and Learning Communication Skills in Medicine. Oxford: Radcliffe; 2005.

40. Hulsman RL, van der Vloodt J. Self-evaluation and peer-feedback of medical students' communication skills using a web-based video annotation system. Exploring content and specificity. Patient Educ Couns. 2015;98(3):356-363.

41. Cavalcanti RB, Sibbald M. Am I right when I am sure? Data consistency influences the relationship between diagnostic accuracy and certainty. Acad Med. 2014;89(1):107-113.

42. Thiede KW, Anderson MCM. Summarizing can improve metacomprehension accuracy. Contemp Educ Psychol. 2003;28(2):129-160. 


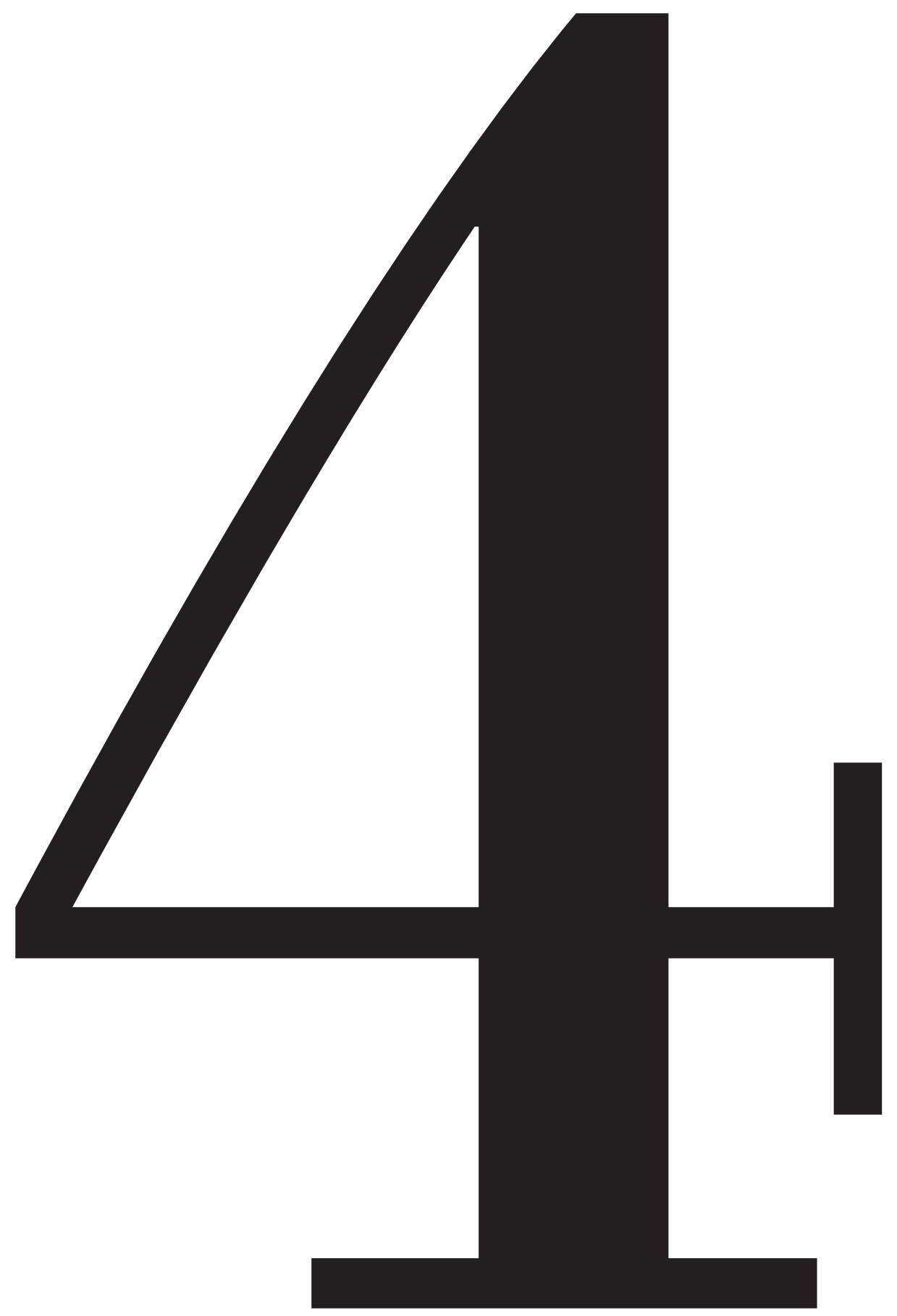




\section{Chapter 4}

\section{Monitoring of history-taking}

performance: Students with superior consultation skills focus more on the patient

Michaela Wagner-Menghin Anique B.H. de Bruin Jeroen J.G. van Merriënboer 


$$
5
$$




\title{
Chapter 5
}

\begin{abstract}
Communication skills supervisors' monitoring of history-taking performance: How doctors and nondoctors use cues to prepare feedback
\end{abstract}

Michaela Wagner-Menghin Anique B.H. de Bruin Jeroen J.G. van Merriënboer 


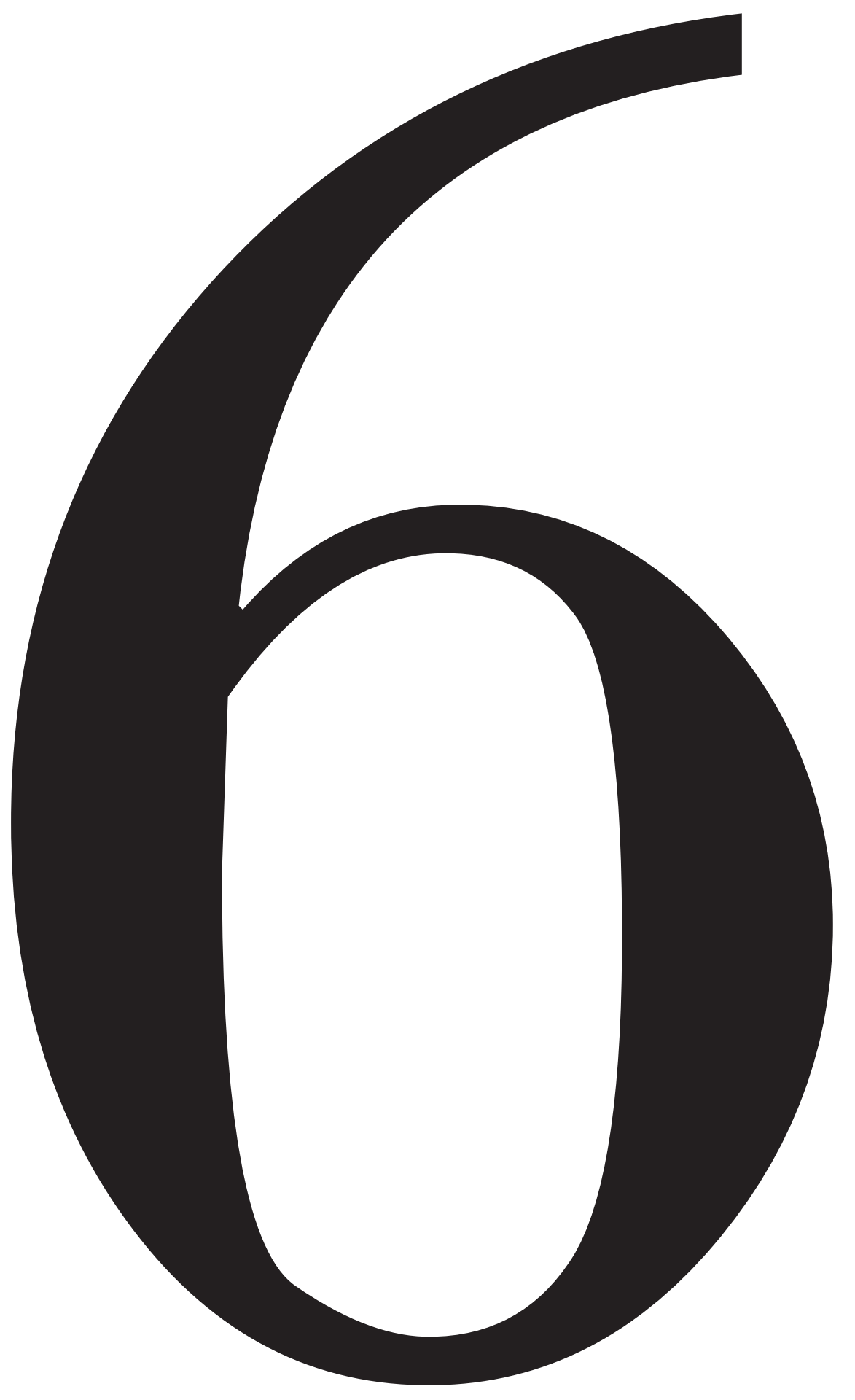


Chapter 6

General Discussion 
Chapter 6 
Medical educators call for educational interventions to improve students' selfjudgement accuracy when learning to take a patient's history as the accuracy of selfjudgements is essential to effective self-regulation. ${ }^{1-3}$ The research objectives pursued in this thesis helped to provide empirical evidence informing the development of effective educational interventions. This included proposing a theoretical model of students' monitoring and cue-utilisation when self-judging history-taking performance (research objective 1), providing empirical results on students' cue-utilisation when practicing in the skills lab (research objective 2), and investigating supervisors' cue-utilisation when preparing for giving feedback (research objective 3). The following sections summarize main findings, discuss theoretical contributions as well as limitations, and give implications for the practice of teaching and learning history-taking.

\section{Main findings}

\section{Research Objective 1: Understanding the mechanism of self-monitoring as rela- ted to history-taking}

Adopting the cue-utilisation framework ${ }^{4}$ in Study 1 to model students' monitoring processes led to explanation of accurate self-monitoring as a result of using relevant cues when deriving a self-judgement. Within this framework, 'metacognitive prompts', which activate the underlying knowledge and skills (= cognitive schemas), when responding to the prompts, improve the access to relevant cues. ${ }^{5-7}$

A relevant finding was that to deal with the complexity of the different knowledge and skills domains ${ }^{8-11}$ involved, the process of history-taking was understood as a series of comprehension problems challenging students' self-regulation. The corresponding hierarchical structure of schemas and subschemas, organizing the knowledge and skills needed for solving the challenges, was thus based on three schemas. These included 'developing a communication strategy' (comprehension problem 1), 'communicating with the patient' (comprehension problem 2), and developing a 'patient schema' (comprehension problem 3) to integrate a patient's problems with the student's illness scripts. As each schema was again constituted by three subschemas, it can be concluded that to fully master history-taking the resulting nine different subschemas all have to be built in a balanced way. It follows that self-monitoring during learning has to target at activating all the subschemas and the overarching schemas to contribute not only to their systematic refinement during practice, but also to their integration. This means that to improve the accuracy of these monitoring processes, prompts for activating nine different subschemas and three overarching schemas are necessary.

The main finding related to research objective 1 was that when talking about accurate self-judgements, knowing what schema and subschema should currently be learned is crucial. Comparing self-monitoring judgements with external standards, such 
as supervisors' judgements is only meaningful when both target at the same schema or subschema (Chapter 2). Therefore, it was subsequently explored empirically how students (Research Objective 2) and supervisors (Research Objective 3) use cues for monitoring, using the comprehension problem 2 'communicating with the patient' as an example.

\section{Research Objective 2: Describing how students use cues when self-judging their patient- communication}

To further describe cue-utilisation ${ }^{4}$ when monitoring 'communicating with the patient,' a new introspection approach for data collection and content-analytic analysis was developed to conduct Study 2 and Study 3.

A main finding for the second research objective was that students who selfjudged success in history-taking predominantly used cues as predicted by the cueutilisation framework ${ }^{4}$ and recommended by the established patient-communication teaching framework. ${ }^{12}$ They mostly relied on observable cues emitted by the patient and themselves, as well as on memory cues. In addition, cues emerging from conscious and unconscious processing of observable cues and memory cues, such as subjective feeling cues, omission cues and mentalizing cues, informed students' judgements. The cue-utilisation framework ${ }^{4}$ and teaching framework, ${ }^{12}$ however, do not correspond concerning the utilisation of summative-behaviour-descriptors. Although the teaching framework $^{12}$ discourages the utilisation of summative-behaviour-descriptors students used them to elaborate their self-judgements. Like the other emerging cues, summativebehaviour-descriptors manifest themselves when students used adjectives to summarize unconsciously perceived behaviour (e.g., 'friendly'), which is a rather automatized process in adults (Chapter 3).

Another main finding related to research objective 2 is that medical students differing in their performance of basic clinical skills (as assessed at the end of year 2) already differed regarding their cue-utilisation and their monitoring during practicing structured history-taking three months earlier. Superior performers integrated a larger variety of cues into their self-judgements during practicing history-taking, and especially considered patient's experiences (= mentalizing cues) and used summative-behaviourdescriptors. Superior performers were more critical and monitored more performance aspects. They more often monitored the overarching schema 'communicating with the patient', and when monitoring the subschemas 'performing the communication' or their use of 'communication techniques', they focused more on techniques facilitating patients' narrative. In contrast, poor performers monitored 'performing' or their use of 'communication techniques' and focused on techniques for structuring the encounter. Poor performers engaged heavily in monitoring how well they covered the topics of the content guide, a monitoring activity, contributing to the 'patient schema', and not necessarily to 'communicating with the patient' schema (Chapter 4). 
Summarizing the main findings regarding the second research objective it can be said that students used cues as described by the cue-utilisation framework ${ }^{4}$ and the patientcommunication teaching framework, ${ }^{12}$ except for summative-behaviour-descriptors. Although using personality adjectives when talking about others' performance when feedback giving is discouraged, ${ }^{12}$ superior as well as poor performers used adjectives when elaborating on their self-judgements. But while superior performers seemed to use emerging personality adjectives as cues to 'take a closer look' and identified underlying observable cues, memory cues or other emerging cues, poor performers' monitoring seemed not to be deepened by the emergence of summative-behaviour-descriptors. Instructing students how to use summative-behaviour-descriptors constructively to improve monitoring might thus be a promising approach to guide students' monitoring. Therefore, it was subsequently explored empirically how supervisors use cues for monitoring when preparing for giving feedback (Research Objective 3).

\section{Research Objective 3: Describing how supervisors use cues when judging others' patients communication to prepare feedback}

To use the newly adapted cue-utilisation framework ${ }^{4}$ (research objective 2 ) to describe the supervising of 'communicating with the patient', an adapted version of the introspection approach for data collection and content analytic analysis had to be developed for Study 4.

A main finding was that doctors and non-doctors adaptively used observable cues to judge distinct aspects of history-taking, as recommended by the patientcommunication teaching framework ${ }^{12}$ they were trained on. When judging the structuring of the encounter, they used memory cues and preferred to observe the interviewer above the patient. When judging the facilitating of the narrative, doctors and non-doctors also shifted attention towards observing the patient in order to identify interaction. Both groups also included subjective feelings and mentalizing cues into their judgements. Omission cues, however, were predominantly used by doctors.

Another relevant finding was that in contrast to students, supervisors seemed to have succeeded in avoiding the use of summative behaviour descriptors to elaborate judgements more successfully. The cue-utilisation framework defines summativebehaviour-descriptors as experiential cues. As they emerge from unconsciously processing situational information, they can be a valuable cue informing first supervisors' judgement and subsequently their feedback giving. To prepare effective feedback supervisors thus have to notice these emerging inferences and link them to observable behaviour or memory content. When supervisors then succeed in presenting a metacognitive prompt to the student, the student will not only notice the relevant behaviour but potentially make a similar inference. Following suggestions on how to improve behaviour is most likely more welcome after having noticed oneself what went wrong than without having noticing oneself what went wrong (Chapter 5). 


\section{Theoretical and Methodological Contributions}

Providing answers to the three research objectives outlined above led to four theoretical contributions and one methodological contribution. These included to reframe history-taking as solving three comprehension problems and to add the self-regulation framework to the well-established conversational model for history-taking. Beyond that, the research at hand contributed to modelling cue-utilisation when monitoring patientcommunication and to derive a self-regulation oriented model for feedback giving. Owing to the pioneering character of the research, also a methodological contribution, thus being a research procedure for capturing utilisation of cues systematically, was listed. The following sections elaborate on these contributions.

\section{Understanding history-taking as solving three comprehension problems}

The research at hand assumed similarities between comprehending a patient's story while taking history ${ }^{12}$ and comprehending a text's meaning while reading. ${ }^{13}$ Both share the cognitive process of 'comprehending' although there are notable differences in accessing the information one aims to understand. Comprehending goes beyond understanding the underlying meaning of every single piece of information. It involves integrating meaning across these pieces and across relevant background knowledge to generate inferences, and 'reading between the lines' to learn about the author's motive or about how patient's disease and illness can be cured or relieved with the help of medical knowledge.

The resulting theoretical step of defining learning as a self-regulation problem, requiring domain-specific knowledge and skills, is not new in itself but it is new in the domain of history-taking. Taking a self-regulation perspective, learning to take patients' histories in the workplace can be structured around three comprehension problems, which challenge students' self-regulation. First, students have to comprehend the needs of the medical setting and their own needs in order to optimize the 'communication strategy' (comprehension problem 1; Figure 1, upper box) which still leaves room for patients' needs. Second, students have to comprehend how to best 'communicate with the patient' (comprehension problem 2, Figure 1; middle box) and integrate patient's needs in their communication strategy. Third, students have to comprehend the patient information in light of relevant medical knowledge to develop a 'patient schema' (comprehension problem 3; Figure 1, bottom box).

The added value of taking a self-regulation perspective on learning history-taking lies in guiding the way to improve students' self-judgement accuracy, by establishing a theoretical connection with a well-established body of research on improving text comprehension. In this field, 'metacognitive prompts' have been developed to help students self-judge their degree of comprehension. 


\section{Self-regulation oriented conversational model for history-taking}

Taking a self-regulation perspective on history-taking consequently leads to expanding the well-established conversational model for history-taking outlined by Silverman, Kurz and Draper, ${ }^{10}$ while emphasizing its core proposition: Communication content aspects and communication process aspects should be combined adaptively to integrate doctor's and patient's position. Besides structuring history-taking as three comprehension problems, the research contributed the threefold schema/ subschema structure to describe the self-regulated learning process with respect to each comprehension problem more closely. Being new to clinical settings, students have to start working on comprehending how to best plan the 'communication strategy' for the given setting. Therefore they have to integrate their knowledge on 'communicative functions and goals' with 'medical setting's requirements' and their own 'learning

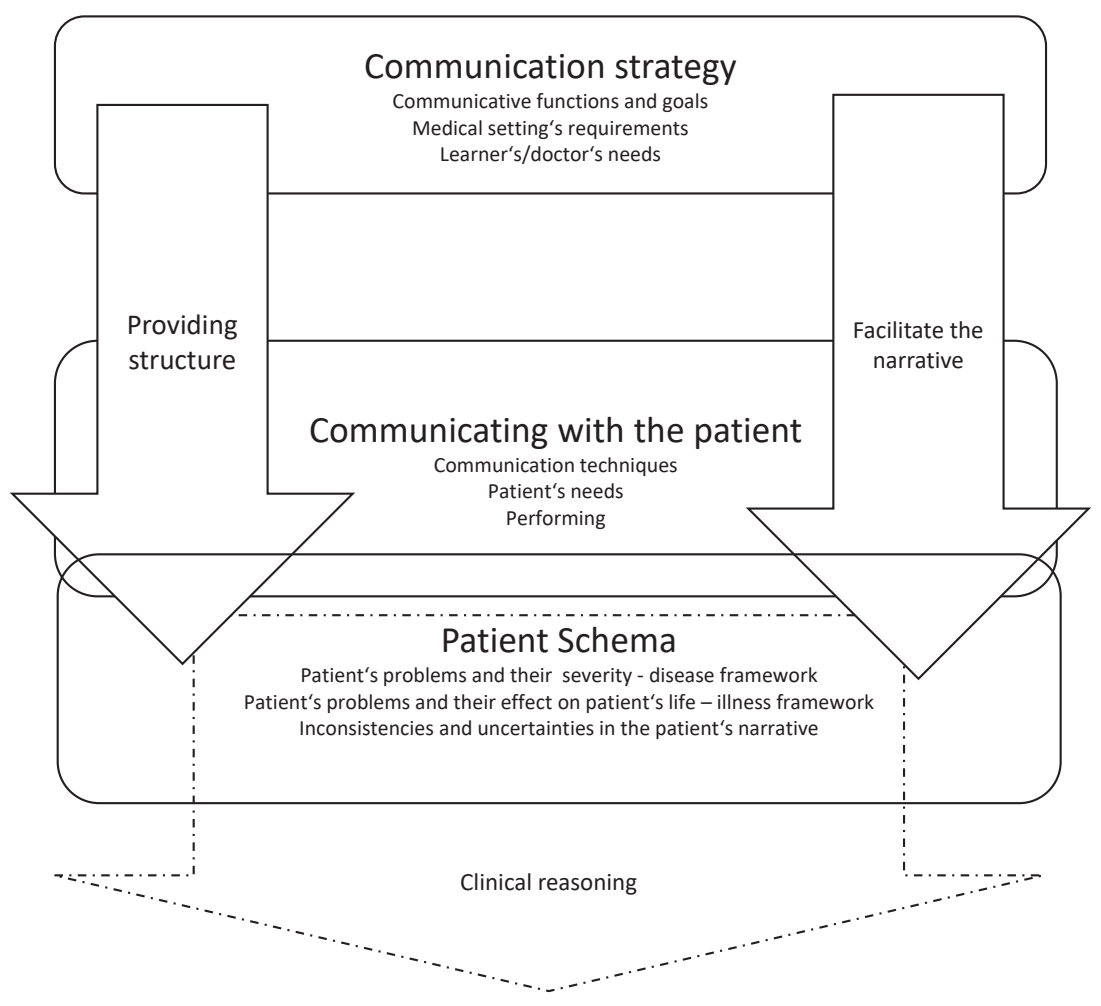

Figure 1: Expanded version of the conversational model for history-taking by including the cognitive schemas and subschemas active when solving the three comprehension problems of history-taking. Conversational model adapted from Silverman, Kurz and Draper (2005) ${ }^{10}$ 
needs'. Thus working on acquiring the knowledge as defined by these three constituting subschemas will support learners' comprehension of how to develop the communication strategy (Figure 1, upper box). Only when learners understand what they are required to do in a given history-taking setting, can they effectively provide structure for the patient during the encounter (Figure 1, arrow left). Additionally, they have their mind free to concentrate on how to 'communicate with the patient'. ${ }^{11,14,15}$ Solving this problem entails to integrate knowledge on 'communication techniques', with 'patient's needs' and to master the 'performing' of the communication (Figure 1, middle box). Only then can students facilitate the narrative to gather relevant patient information (Figure 1 , arrow right). In return, this is a prerequisite for comprehending a patient's problem. Developing one's 'patient schema' entails to translate information on 'patient's problems and their severity (disease framework)' as well as 'patient's problems and their effect on patient's life (illness framework)'. It also entails structuring the information received by the patient meaningfully to facilitate its integration with medical knowledge in the form of illness scripts (Figure 1, bottom box). Only then inconsistencies and uncertainties in the patient's narrative' can be detected and the diagnostic process can be driven or ideas for treatment can be developed (Figure 1, dotted arrow 'clinical reasoning').

It has been decided to depict the self-regulation oriented model of historytaking with the novice learner in mind. It has been assumed that these students are not yet fully able to solve both the 'communicating' and the building of 'patient schema' problem during the encounter. Thus, the box representing the 'communicating with the patient' and the box 'patient schema' have been depicted with only limited overlap. For more experienced learners there should be more overlap between these boxes, and for them an arrow 'clinical' reasoning should be added at the bottom following the 'patient schema box' until for experts the boxes cover each other and run parallel with the clinical reasoning arrow.

The added value of using a self-regulation oriented conversation model lies in its ability to serve students, skills lab teachers, and clinical supervisors as a roadmap to guiding students' learning. It can be used to establish a meaningful connection between what is commonly learned and practiced in a skills lab ('communicating with patient') and what students are meant to learn and practice in the workplace ('communication strategy', 'communicate with patient', 'patient schema'). Teachers in the skills lab should take care to carefully point out to students which schemas/subschemas they can practice in class and which not. For those that can't be addressed in class, skills lab teachers still may provide students with strategies how to best practice at the workplace. Clinical supervisors in workplace-based-learning should encourage students to approach one comprehension problem after the other in their own pace and not try to apply the 'all at once' approach of experienced clinicians immediately. 


\section{Using cues when monitoring patient-communication}

The conducted empirical studies yield a cue-utilisation framework for patientcommunication, which is tested for students and supervisors when monitoring one's own or others' patient-communication as related to history-taking.

Important observable cues informing self-judgements are patient's verbal and non-verbal behaviour and interviewer's verbal and non-verbal behaviour. These form the even more meaningful reciprocity cue, when relating patient's behaviour to student's behaviour or vice versa (e.g. 'I asked two questions at once, as a result my patient didn't know which one to answer and looked confused'; 'the patient expressed his anger about being treated by a student and I explained, that I as a junior member in the team have been trained in gathering and preparing key information for the responsible physician'). (Figure 2, box 'Observable cues'). When observable behaviour cues are unconsciously combined with relevant memory cues, the experiential cues emerge in consciousness. Amongst them are subjective feelings, which express general positive feelings (e.g., fluency, appropriateness) or negative feelings (lack of fluency, lack of appropriateness), related to performing. Inferences about how the patient feels and thinks in the situation (=mentalizing cues) are also an important source of information when self-judging one's patient-communication performance. Owing to the fact that there is evaluation of human behaviour involved, inferences about behaviour are expressed in the form of adjectives (=summative-behaviour-descriptors). Omission cues have a special function; their emergence commonly leads to a not-satisfied judgement, as they indicate that the interviewer forgot to explore relevant detail (Figure 2, box 'Experiential cues').

The added value of the cue-utilisation model on monitoring history-taking in its current form is threefold. First, the model helps illustrate in which type of monitoring process students engage spontaneously and which type of cues they pay attention to, when confronted with a general monitoring prompt. There is first insight that matching with their level of education all undergraduate students practicing in the skills lab engaged in monitoring the 'performing of the communication' including 'communication techniques', both subschemas of the overarching 'communicating with patient' schema. But only those generally showing superior performance in basic clinical skills also engage in monitoring the appropriateness of the process skill utilized in view of the goal to be attained, thus tapping into monitoring the overarching 'communicating with patient' schema. Besides that, predominantly poor performing students engaged in monitoring if they covered all items of their content guide, thus monitoring subschemas of the 'patient schema'. This illustrates that monitoring processes stimulated by unspecific monitoring prompts are not necessarily effective in all students. When they do not engage in detail in monitoring the subschemas as suggested by the self-regulation oriented model for history-taking, they might fail to effectively build and integrate relevant knowledge and skills. 


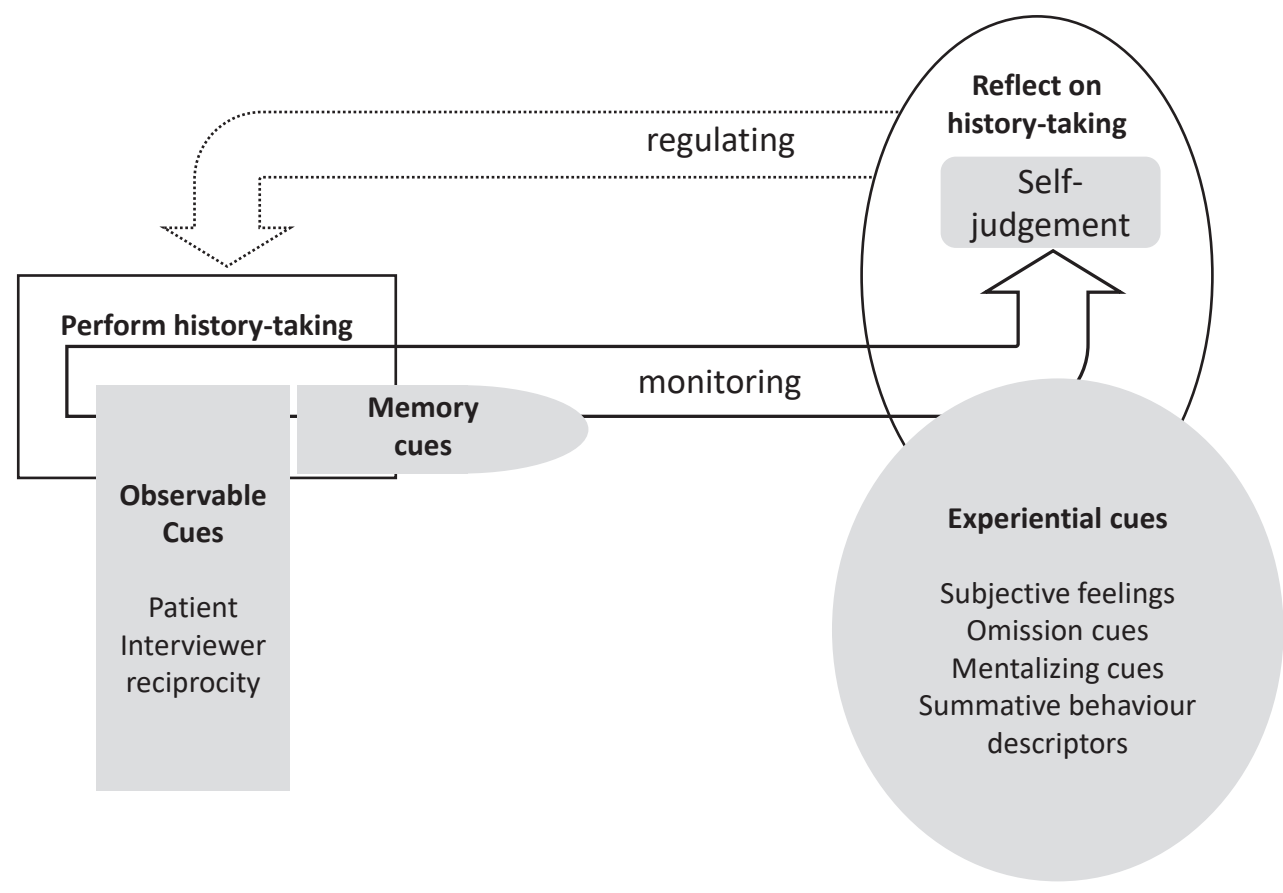

Figure 2: Cues identified as informing the self-judgement of patient-communication during historytaking

Second, the model has potential to serve as a starting point for testing systematically which cues or which combinations of cues are most predictive for the single schemas/subschemas. There is first insight that paying attention to cues such as mentalizing cues is beneficial for all types of monitoring processes, and that including more cues rather than fewer cues also seems to be beneficial.

Third, the model can serve to assess the effectivity of different prompts in stimulating cue-utilisation. A relevant future goal thus might be to compare effectiveness of using only one prompt to stimulate the overarching subschema as compared to using multiple prompts stimulating each subschema individually.

\section{Self-regulation oriented model for feedback giving}

The studies conducted with the patient-communication supervisors also yielded a self-regulation oriented model for feedback giving. This model expands the established model of descriptive feedback giving (Figure 3, dashed path on the upper right edge). In the new model the descriptive feedback giving is only done after having presented suitable metacognitive prompts to the student (Figure 3, dashed path on the lower right edge). 


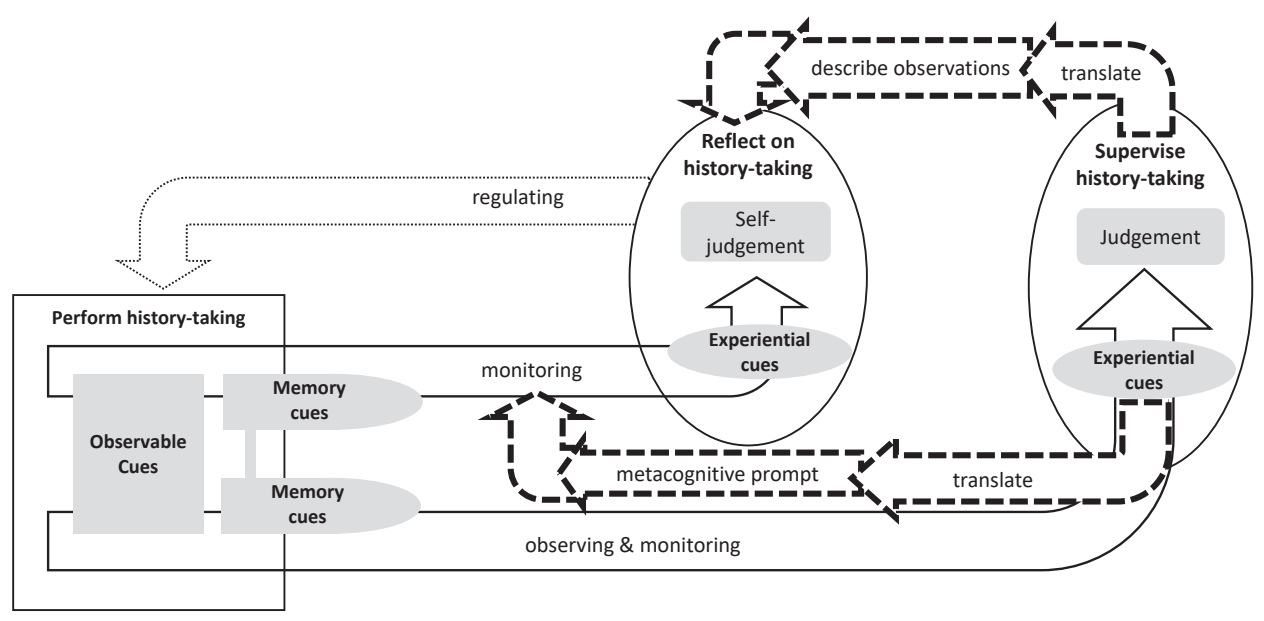

Figure 3: Using cues for self-judgement and feedback giving in patient-communication during historytaking.

This new model of feedback giving understands this process as two translation challenges. First, the supervisor has to be aware of emerging/experiential cues. These have to be translated into metacognitive prompts instead of communicating the nature of the prompts. Second, the supervisor has to be aware of his/her judgement of the situation and translate it into a description of behaviour and into a non-violent expression in how the supervisor felt himself/herself. The added value of the self-regulation oriented model for feedback giving lies in its potential to translate all naturally emerging cues into meaningful feedback for the student.

\section{Provide a research procedure for capturing cue-utilisation systematically}

Previous studies on metacomprehension predominantly focussed on experimentally manipulating metacomprehension accuracy in order to come up with ideas of how to phrase metacognitive prompts. This project adds the idea to gain more insight in the underlying monitoring processes and into cue-utilisation itself prior to developing and experimenting with metacognitive prompts. To learn how students use cues a research procedure to capture cue-utilisation was developed. It was decided to use an introspective approach as this allowed to observe students' cue-utilisation for monitoring closely related to their learning. 


\section{Limitations}

Despite all new insights, several limitations of the work reported in this thesis can be listed. First, all the empirical studies relied on an introspective approach thus allowing only the access of consciously available information. Asking students to introspect may have altered their nature of introspection already. Taking into account that self-regulation during learning also requires relevant cognitions emerging in consciousness, developing new research procedures beyond introspection may not have first priority, despite being of theoretical interest.

Furthermore, we observed only undergraduate medical students during learning in the safe environment of the skills lab. Thus, our findings concerning cueutilisation are not necessarily generalizable to students learning in the workplace or to more advanced learners. Further research including those learning environments and those learners is necessary.

Moreover, the study comparing high performing and poor performing students' cue-utilisation used a case-control design. Although the study has been able to control for effects of the training group the students were trained in, or effects of the teacher the students were trained by, there is still a need for prospective cohort studies to understand how cue-utilisation changes with developing performance. The study comparing doctors' and non-doctors' cue-utilisation used a video showing a seniordoctor as stimulus material. A student model would have been more validly linked to the teachers' task of preparing feedback, thus a video showing an undergraduate student would possibly have brought other results.

The content-analytic approach determining the type of monitoring process students engage in in the empirical studies was informed by the distinction between content aspects and process aspects as defined by the Silverman, Kurz and Draper ${ }^{10}$ model. The theoretical part of our studies, however, indicates a more detailed structure for history-taking as being more appropriate. Thus, the identified monitoring processes resemble the new structure although they do not exactly match this new structure. New studies would benefit by adopting a modified system for content analysis, informed by the theoretical part of the project.

\section{Practical implications for teaching and learning history-taking}

Working on answering questions related to the three research objectives outlined above and using the new insights to expand the underlying theories and models also points the way to four practical implications for the teaching and learning of historytaking. To facilitate students in successfully solving the series of three comprehension problems of history-taking it is suggested that teachers give students an overview about 
them. When adding the self-regulation perspective on history-taking to the wellestablished conversational model for history-taking, it becomes obvious that helping novice learners to comprehend requirements of the clinical setting should be a priority for clinical supervisors. The theoretical model on cue-utilisation when monitoring patient-communication leads to reconsidering the meaning of summative-behaviourdescriptors. Also, having a self-regulation oriented model for feedback giving suggests to reconsider feedback practice during skills training. The following sections elaborate on these practical implications.

\section{Share an overview about all the challenges related to history-taking}

When teachers of communication skills, clinical supervisors and learners of all levels have a better overview of the three comprehension problems challenging self-regulation when learning in the workplace, this can support their teaching and learning. Communication skills teachers giving a course in a skills lab for undergraduate medical students should take care to prepare their learners to be ready to adapt the communication strategy they just practiced in the skills lab once they enter a specific clinical setting. Adapting one's communication strategy is not a sign of 'having learned the wrong stuff' or 'training being useless' but, on the contrary, a sign of being able to integrate situational needs with relevant general principles. Medical students graduating today face a lifetime of practice that will be accompanied by rapid changes in society, technology and medical knowledge. Their ability to integrate new situational requirements when talking to patients will be challenged constantly. Communication skills teachers can support their students by familiarizing them with a set of metacognitive prompts guiding their learning. Clinical supervisors should encourage students to reflect on their learning by using the same prompts as they learned in classroom training to stimulate their reflection.

\section{Help learners to comprehend requirements of the clinical setting}

Clinical supervisors' teaching in the workplace should ensure that their learners receive the information they need to understand and adapt to the clinical setting, and give them enough time to get used to a new strategy. As depicted in Figure 1, understanding what one needs to do in a given setting is fundamental to structuring the encounter and to facilitating the patient's narrative. Thus understanding what one needs to do in a given setting is ultimately fundamental for building the relationship with the patient, which in turn will influence the building of the patient schema. Ideally, clinical supervisors provoke discussion about discrepancies between different medical settings' requirements and the resulting compromises in communication strategies. 


\section{Reconsider feedback practice during skills training}

Given the importance of accurate self-judgements for the uptake of feedback, reconsidering the feedback-giving practice during skills training might be desirable. The current recommendation regarding feedback-giving during communication skills training is to focus on descriptive feedback after having asked the students what they tried to achieve in the preceding practice-session. This practice targets at helping students to compare their current performance with the agreed performance standard, which is regarded as less intrusive as compared to communicating supervisors' positive or negative judgements. To boost learning in the long run, however, the learning sciences advocate prompting students' metacognitions prior to giving descriptive feedback to help students to recognize metacognitive cues which are diagnostic of performance. Supervising doctors and non-doctors need to be trained to give metacognitive prompts to students to initiate metacognitive feedback.

\section{General Conclusion}

The work reported in this thesis increased our understanding of how to promote self-regulated learning of history-taking skills in the workplace in at least three ways. First, structuring history-taking as a composition of three comprehension tasks, opens up the way to learn from meta-comprehension research. Self-judgement accuracy as a predecessor of effective self-regulation can be improved by metacognitive prompts. Second, interviewers (students and doctors) who identify cues indicating the satisfaction of needs of all three parties involved (interviewer, patient, medical setting), will be able to communicate better with their patients (comprehension problem 2). They will also be able to make better decisions on how to take a patient's history, because necessary compromises can become obvious and balanced. Third, there is yet little knowledge available on how to support students in understanding the requirements of the clinical setting to develop their communication strategy (comprehension problem 1), and how to help them combine information from patients with their medical knowledge in order to develop a patient schema (comprehension problem 2). To further expand our knowledge of how to guide students' reflections in/on action when taking history, future research should look for predictive cues that help them to develop a successful communication strategy and to construct a rich patient schema. 


\section{References}

1. Koriat A. The relationships between monitoring, regulation and performance. Learn Instr. 2012;22(4):296-298.

2. Dunlosky J, Thiede KW. Four cornerstones of calibration research: Why understanding students' judgments can improve their achievement. Learn Instr. April 2013;24:58-61.

3. de Bruin A, Dunlosky J, Cavalcanti RB. Monitoring and regulation of learning in medical education: the need for predictive cues. Med Educ. 2017;51(6):575-584.

4. Koriat A. Monitoring one's own knowledge during study: A cue-utilization approach to judgments of learning. J Exp Psychol Gen. 1997;126(4):349-370.

5. Rawson KA, Dunlosky J. Improving students' self-evaluation of learning for key concepts in textbook materials. Eur J Cogn Psychol. 2007;19(4-5):559-579.

6. Lipko AR, Dunlosky J, Hartwig MK, Rawson KA, Swan K, Cook D. Using Standards to Improve Middle School Students' Accuracy at Evaluating the Quality of Their Recall. J Exp Psychol Appl. 2009;15(4):307-318.

7. Martin D, Regehr G, Hodges B, McNaughton N. Using Videotaped Benchmarks to Improve the Self-assessment Ability of Family Practice Residents. Acad Med. 1998;73(11):1201-1206.

8. Smith RC, Hoppe RB. The patient's story: integrating the patient- and physician-centered approaches to interviewing. Ann Intern Med. 1991;115(6):470-477.

9. Langewitz W. Integration der patientenzentrierten und der arztzentrierten Gesprächsführung. In: Langewitz W, Daetwyler C, Guttormsen-Schaer S, Schnabel K, eds. DocCom Deutsch. Medienunterstützte online Module für die Aus-und Weiterbildung in Kommunikation im Gesundheitswesen. https://doccom.iml.unibe.ch. Bern (Switzerland): Universität Bern; 2014.

10. Silverman J, Kurtz S, Draper J. Skills for Communicating with Patients. Oxford: Radcliffe; 2005.

11. Salmon P, Young B. Creativity in clinical communication: from communication skills to skilled communication. Med Educ. 2011;45(3):217-226.

12. Kurtz S, Silverman J, Draper J. Teaching and Learning Communication Skills in Medicine. Oxford: Radcliffe; 2005.

13. Thiede KW, Wiley J, Griffin TD. Test expectancy affects metacomprehension accuracy. Br J Educ Psychol. 2011;81(2):264-273.

14. Rosenbaum ME, Axelson R. Curricular disconnects in learning communication skills: What and how students learn about communication during clinical clerkships. Patient Educ Couns. 2013;91(1):85-90.

15. Aper L, Veldhuijzen W, Dornan T, et al. "Should I prioritize medical problem solving or attentive listening?": The dilemmas and challenges that medical students experience when learning to conduct consultations. Patient Educ Couns. 2015;98(1):77-84. 


$$
\mathrm{A}
$$




\section{APPENDIX}

English Summary

Nederlandse Samenvatting

Valorisation Addendum

Acknowledgements

Curriculum Vitae 
Appendix 


\section{ENGLISH SUMMARY}

History-taking is a highly complex skill because patient-communication skills gradually have to blend in with clinical reasoning skills to steer effective information gathering. Despite the importance of clinical reasoning in this process, research has shown the importance of good patient-communication for effective information gathering. Thus, in general, history-taking training starts already in undergraduate medical curricula with structured training in the skills labs and focusses on how to best 'communicate with the patient'. As at this educational level students' limited medical knowledge precludes effective clinical reasoning, their history-taking is mostly guided by a comprehensive content list. Despite prior training in the skills lab, transitioning to workplace-based learning in clinical practice challenges students' self-regulation of learning. It is difficult for students to adapt to busy workplace routines and to meaningfully contribute to diagnostic routines, because of their still limited clinical reasoning ability. Also a lack of meaningful feedback on their performance challenges students' self-regulation. To benefit from workplace-based training students are dependent on self-judging how they are doing and act upon their self-judgements.

Yet, it has been well established that in general students are inaccurate in selfjudging their learning, mostly because they base their judgements on information (=cues) that is not predictive of their current or their later performance. However, it is possible to help students in self-judging more accurately by giving them so-called 'metacognitive prompts,' which they can react to prior to self-judging. Answering the prompts activates the same knowledge and skills, so called cognitive schemas, as required for working on the task itself. As a result, prompts help to draw a student's attention towards predictive cues. Additionally, the generation of answers to the prompts gives rise to so-called subjective feelings that can also be used as cues.

To support medical students' learning of history-taking in the workplace their monitoring and self-judgement skills should be trained alongside their patientcommunication skills. But until now, almost no results have been presented in the literature concerning improvement of students' self-regulation skills in the domain of patient-communication for history-taking. In addition, no results on students' cueutilisation when self-judging history-taking are available to inform the development of suitable metacognitive prompts.

Therefore, to gain further insight in how to boost self-regulated learning of history-taking by improving students' use of predictive cues when making selfjudgements three research objectives were addressed in this thesis. The first research objective was to understand the mechanism of self-judgements related to history-taking. Cognitive theory on self-monitoring and complex skill acquisition was integrated with literature on history-taking and patient-communication to present a general model of self-monitoring of history-taking (Study 1). The second objective aimed at describing 
how students proceed when self-judging their patient-communication based on this model. Study 2 developed a content coding system and systematically described how students actually monitor their history-taking and how they use cues. Study 3 compared how superior performing students versus poor performing students differ with respect to their cue-utilisation. The third objective took into account that history-taking performance and communication skills are commonly assessed by observing students and rating their performance. The general model of self-monitoring was expanded to explore empirically how patient-communication teachers monitor their students' history-taking when preparing feedback. This also paved the way for improving accuracy of teachers' external judgements (Study 4).

With regard to the first research objective, Study 1 suggested to structure historytaking as a series of three comprehension problems, challenging students' self-regulation. Being new in a clinical setting, students have to comprehend the medical setting's requirements and integrate them with their knowledge and their learning needs. Only then can students develop a suitable 'communication strategy' (comprehension problem 1) to meaningfully structure the patient encounter. During the patient encounter students have to comprehend the patient's communication needs. This enables them to facilitate the patients' narrative and gather relevant information by means of 'communicating with the patient' (comprehension problem 2). Comprehension problem 3 entails understanding the patient's problems and to structure them in medical terms. Only then this 'patient schema' can be combined with medical knowledge, organized in illness scripts, to inform the clinical reasoning process. Based on this self-regulation model of history-taking, metacognitive prompts, activating each of the underlying schemas and its constituting subschemas, were suggested. These prompts are now available for further refining and for testing their effects on stimulating the utilisation of predictive cues when monitoring ones understanding of each of the three problems.

The empirical Study 2 addressed the second research objective. It explored students' cognitions when self-judging 'communicating with the patient' by soliciting self-judgements of their history-taking skills, coined Judgements of Satisfaction (JOSs). An introspection procedure and a content analytic analysis were newly developed to conduct the study. When self-judging their satisfaction with patient-communication following history-taking in a skills lab, students utilized observable cues emitted by the patient and the interviewer, together with experiential cues. These experimental cues include all inferences made by unconsciously processing observed behaviour and memory content. Amongst the identified experiential cues related to history-taking were general subjective feelings (e.g., fluency), inferences about patient's experiences (called mentalizing cues), inferences about personality traits (e.g., 'friendly'; called summativebehaviour-descriptors), as well as inferences about one's (lack of) success in covering the topics of the content guide (called omission cues).

Further contributions to the cue-utilisation model for history-taking, addressing 
the second research objective, came from Study 3. It used the procedure developed in Study 2 to compare cue-utilisation of students with superior versus poor basic clinical skills performance. Superior performers integrated several different types of cues in their self-judgements and they used mentalizing cues more often. Surprisingly, they also used summative-behaviour-descriptors rather often, although their use is generally discouraged by the current patient-communication teaching framework. Approximately one third of students' judgements focused on content, thus being the information gathered, and about half on the quality of performing the communication skills. About $10 \%$ targeted the appropriateness of the communication skills used and it was primarily superior-performance students who formed this type of judgements. Additionally, superior performers were found to self-judge scenes more often as 'not-satisfactory' than poor performers.

Study 4 addressed research objective three, concerning supervisors' cue-utilisation when monitoring history-taking for preparing feedback. Therefore, the cue-utilisation model for history-taking was expanded to allow the modelling of cue-utilisation with external judgements. The model was tested by comparing doctors' and non-doctors' cue-utilisation. Both groups used observable cues more often than emerging cues, such as subjective feelings and mentalizing cues, but mainly the doctors utilized omission cues. Compared to non-doctors, the doctors described more scenes showing negative performance.

The four studies allow to infer several main findings, theoretical and methodological contributions, and contributions to practice. Main findings from Study 1 led to the development of the self-regulation oriented conversational model of history-taking. To deal with the complexity of the different knowledge and skills domains involved, history-taking was structured as a series of three comprehension problems as already described above. The different knowledge and skills necessary to solve these problems are organised in three schemas, each again constituted by three subschemas. This model implies that when talking about improving self-regulation by facilitating accurate selfjudgements, knowing what schema and subschema should currently be learned and monitored is crucial. Comparing self-monitoring judgements with external standards is only meaningful when both target at the same schema or subschema. The practical implications can be summarized as follows. To facilitate students in successfully solving the series of three comprehension problems of history-taking, teachers should give their students an overview of these problems. Also, helping novice learners to comprehend requirements of the clinical setting should be a priority for clinical supervisors, as this lays the foundation for providing a suitable structure during history-taking with the patient and thus contributes to patient's narrative.

The main findings from Study 2 and Study 3 informed the development of the cue-utilisation model for 'communicating with the patient'. Students' self-judging their success in 'communicating with the patient' predominantly used cues as predicted by 
the general cue-utilisation framework and as recommended by the established patientcommunication teaching framework - except for summative-behaviour-descriptors. Although their utilisation is discouraged, superior performers as well as poor performers used them. However, superior performers generally integrate more different types of cues into their self-judgements during practicing history-taking, especially mentalizing cues. It can thus be inferred that superior performers utilize the emergence of summativebehaviour-descriptors in their consciousness as a prompt to dig deeper and to look for relevant observable behaviour cues and other emerging cues. The practical implication related to these studies suggested to reconsidering the meaning of summative-behaviourdescriptors. Instead of discouraging their use, it should be emphasized to use them as a cue indicating the need for further reflection.

Relevant findings comparing cue-utilisation of doctors and non-doctors for preparing feedback giving (Study 4) suggest a self-regulation oriented feedback procedure. Both groups of supervisors adaptively used observable cues to judge the quality of history-taking, as recommended by the patient-communication teaching framework they were trained on. When judging the structuring of the encounter they used memory cues and preferred to observe the interviewer rather than the patient. When judging the facilitation of the narrative, doctors and non-doctors also shifted attention towards observing the patient in order to identify interaction. Both groups also included subjective feelings and mentalizing cues into their judgements. Omission cues, however, were predominantly used by doctors. Both groups were found to be well prepared to communicate their observations and thus provide descriptive feedback in the way it is suggested by the patient-communication teaching framework used to train interviewing skills to undergraduates. The practical implication of this study is the suggestion to further improve the feedback giving process. Supervisors should be trained to recognize emerging cues, such as subjective feelings and mentalizing cues, as valid sources of feedback and they should learn how to convert them into meaningful metacognitive prompts for students, prior to giving their descriptive feedback.

Decisions on how to approach the three research objectives inevitably led to limitations. Asking somebody to introspect may already alter the phenomenon of study; yet, it was decided to live with this problem because learning also requires conscious processing. It was decided to observe undergraduate medical students for developing the cue-utilisation model, mainly because these students were readily available. Further research including other learning environments and other groups of learners is necessary. Moreover, the study comparing high performing and poor performing students' utilisation of cues used a case-control design, so there is a need for prospective cohort studies to understand how cue-utilisation changes with developing performance. The theoretical contributions described also show a limitation as related to our contentanalytic approach. It was originally informed by the distinction between content aspects and process aspects as defined by the patient-communication teaching framework. But 
as the theoretical part of our studies indicated a more detailed structure for historytaking, new studies would benefit from adopting a modified system for content analysis.

Ultimately, it was concluded that improving self-judgement accuracy as a predecessor of effective self-regulation requires first dealing with the complexity of history-taking. Only then measures to improve the monitoring of each aspect of historytaking can be taken. The literature on communicating with patients and new results on cue-utilisation as related to 'communicating with the patient' allowed us to propose a cue-utilisation model for the second comprehension problem ('communicating with the patient'). Metacognitive prompts derived from this model can be tested for their effects on self-regulation. Knowledge on how to support students in solving the first comprehension problem ('communication strategy'), and the third comprehension problem by helping them combine information from patients with their medical knowledge in order to develop a 'patient schema', should be further developed by educationalists and clinicians.

From a self-regulation point of view, improving students' use of observable and experiential cues when self-judging their history-taking performance, will help them to better balance the needs of all parties involved. Eventually, this will not only improve communication with the patient, but also the clinical reasoning informed by the gathered information. 
Appendix 


\section{NEDERLANDSE SAMENVATTING}

Het afnemen van een anamnese is een zeer complexe vaardigheid, omdat patiëntcommunicatievaardigheden geleidelijk aan geïntegreerd moeten worden met klinisch-redeneervaardigheden zodat er gericht en effectief informatie kan worden verzameld. Ondanks het belang van klinisch redeneren in dit proces, heeft onderzoek aangetoond dat goede patiëntcommunicatie minstens zo belangrijk is voor effectieve informatieverzameling. Anamnesetraining begint dus over het algemeen al in de curricula van de bachelor geneeskunde met gestructureerde training in de skillslabs en richt zich op de vraag 'Hoe het beste te communiceren met de patiënt?'. Aangezien op dit onderwijsniveau de beperkte medische kennis studenten belet om effectief klinisch te redeneren, worden zij bij het afnemen van een anamnese meestal gestuurd door een uitgebreide inhoudslijst. Ondanks voorafgaande training in het skillslab doet de overgang naar werkplekleren in de klinische praktijk een flink beroep op het zelfregulerend leervermogen van studenten. Het is moeilijk voor studenten om zich aan te passen aan drukke werkplekroutines en om op zinvolle wijze bij te dragen aan diagnostische routines, omdat hun klinisch redeneervermogen nog steeds beperkt is. Ook een gebrek aan zinvolle feedback op hun functioneren bemoeilijkt deze zelfregulatie door studenten. Om baat te hebben bij de werkplektraining zijn studenten aangewezen op hun zelfbeoordeling van hun functioneren en hun handelen naar deze zelfbeoordelingen.

Het is echter ruimschoots vastgesteld dat studenten over het algemeen niet zo goed in staat zijn om hun leren juist te beoordelen, voornamelijk omdat zij hun beoordelingen op informatie (= aanwijzingen) baseren die niet voorspellend is voor hun huidige of toekomstige functioneren. Desondanks is het mogelijk studenten te helpen zichzelf beter te beoordelen door hun zogenaamde "metacognitieve stimuli" te geven waarop zij voorafgaande aan de zelfbeoordeling kunnen reageren. Door deze stimuli te beantwoorden, worden dezelfde kennis en vaardigheden, zogenoemde cognitieve schema's, geactiveerd als die vereist zijn voor het werken aan de taak zelf. Hierdoor helpen stimuli studenten te attenderen op voorspellende aanwijzingen. Bovendien wekt het genereren van antwoorden op de stimuli zogenaamde subjectieve gevoelens op die ook als aanwijzingen kunnen worden aangewend.

Om geneeskundestudenten te ondersteunen bij het leren van anamneses op de werkplek moeten hun monitoring- en zelfbeoordelingsvaardigheden, alsmede hun patiëntcommunicatievaardigheden getraind worden. Tot op heden zijn er in de literatuur echter vrijwel geen resultaten gepresenteerd met betrekking tot het verbeteren van zelfregulatievaardigheden van studenten op het gebied van patiëntcommunicatie ten behoeve van anamneses. Daarbij komt dat er geen resultaten beschikbaar zijn omtrent het gebruik van aanwijzingen door studenten bij het beoordelen van hun eigen anamneses waarop de ontwikkeling van geschikte metacognitieve stimuli zou kunnen 
worden gebaseerd.

Om meer inzicht te verkrijgen in de vraag hoe we het zelfregulerend leren van anamneses kunnen bevorderen door ervoor te zorgen dat studenten beter gebruik maken van voorspellende aanwijzingen bij hun zelfbeoordelingen, stonden in dit proefschrift daarom drie onderzoeksdoeleinden centraal. Het eerste onderzoeksdoel was om de werking van zelfbeoordelingen in het kader van anamneses beter te begrijpen. We integreerden cognitieve theorie over zelfmonitoring en de verwerving van complexe vaardigheden met literatuur over het afnemen van anamneses en patiëntcommunicatie om een algemeen model van zelfmonitoring van anamneses te kunnen presenteren (Studie 1). Het tweede doel was om aan de hand van dit model te beschrijven hoe studenten te werk gingen tijdens het beoordelen van hun eigen patiëntcommunicatie. Studie 2 ontwikkelde een coderingssysteem en beschreef op systematische wijze hoe studenten hun anamneses nu eigenlijk monitoren en hoe zij daarbij gebruik maken van aanwijzingen. Studie 3 vergeleek hoe goed presterende studenten verschilden van slecht presterende studenten met betrekking tot hun gebruik van aanwijzingen. De derde doelstelling hield rekening met het feit dat anamneseprestaties en communicatieve vaardigheden veelal worden beoordeeld door studenten te observeren en een score toe te kennen aan hun prestaties. Het algemene model van zelfmonitoring werd uitgebreid om empirisch te kunnen onderzoeken hoe docenten patiëntcommunicatie de afname van anamneses door studenten monitoren bij het voorbereiden van feedback. Dit effende ook het pad voor het verbeteren van de juistheid van de externe beoordelingen van docenten (Studie 4).

Wat het eerste onderzoeksdoel betreft, stelde Studie 1 voor om de afname van anamneses te ordenen als een reeks van drie begripsproblemen die zelfregulatie door studenten bemoeilijken. Als nieuwelingen in een klinische omgeving moeten studenten de vereisten van deze medische setting begrijpen en deze met hun eigen kennis en leerbehoeften integreren. Pas dan kunnen studenten een passende communicatiestrategie ontwikkelen (begripsprobleem 1) waarmee zij op zinvolle wijze het patiëntenbezoek vorm kunnen geven. Tijdens het patiëntencontact moeten studenten de communicatiebehoeften van de patiënt begrijpen. Dit stelt hen in staat het patiëntenverhaal aan te sturen en relevante informatie te verzamelen door 'met de patiënt te communiceren' (begripsprobleem 2). Begripsprobleem 3 houdt in dat studenten de klachten van de patiënt begrijpen en deze in medische zin weten te ordenen. Pas dan kan dit 'patiëntschema' samengevoegd worden met medische kennis en worden ingedeeld in ziektescripts ten behoeve van het klinisch redeneerproces. Op basis van dit zelfregulatiemodel van anamneses werden metacognitieve stimuli voorgesteld die elk van de achterliggende schema's en subschema's activeren. Deze stimuli zijn nu beschikbaar ter verdere verfijning en om te testen welk stimulerend effect zij hebben op het gebruik van voorspellende aanwijzingen bij het monitoren van het eigen begrip van elk van de drie problemen. 
Studie 2 betrof een empirisch onderzoek waarbij het tweede onderzoeksdoel aan de orde kwam. Het onderzocht de kennis van studenten tijdens het beoordelen van hun eigen 'communiceren met de patiënt' door hun te vragen hun eigen anamnesevaardigheden te beoordelen, oftewel naar wat we noemden hun 'beoordelingen van tevredenheid' $\left(\mathrm{JOSs}^{3}\right)$. Om het onderzoek te kunnen uitvoeren, ontwikkelden we een nieuwe introspectieprocedure en een inhoudsanalytische analyse. Bij het beoordelen van hun tevredenheid met de eigen patiëntcommunicatie na het afnemen van een anamnese in een skillslab, gebruikten studenten waarneembare aanwijzingen die de patiënt en de interviewer afgaven, alsook op beleving beruste aanwijzingen. Tot deze experimentele aanwijzingen behoren alle gevolgtrekkingen uit de onbewuste verwerking van waargenomen gedrag en de in het geheugen aanwezige kennis. Onder de geconstateerde belevingsgerelateerde anwijzingen die bij de anamnese werden gebruikt, bevonden zich algemene subjectieve gevoelens (bijv. vlotheid), conclusies over de beleving van de patiënt (ook mentaliserende aanwijzingen genoemd), conclusies over persoonlijke eigenschappen van de patiënt (bijv. 'vriendelijk'; ook summatief-gedragsdescriptoren genoemd), alsook conclusies over het eigen succes (of falen) betreft het behandelen van de onderwerpen in de inhoudslijst (ook omissieaanwijzingen genoemd).

Verdere bijdragen aan het model van aanwijzinggebruik voor het afnemen van anamneses, waarmee het tweede onderzoeksdoel aan de orde werd gesteld, werden geleverd door Studie 3. Het onderzoek bediende zich van de in Studie 2 ontwikkelde procedure om het gebruik van aanwijzingen door studenten met goede en slechte klinische basisvaardigheden met elkaar te vergelijken. De betere studenten integreerden verschillende soorten aanwijzingen in hun zelfbeoordelingen en maakten vaker gebruik van mentaliserende aanwijzingen. Opmerkelijk genoeg maakten ze ook redelijk vaak gebruik van summatief-gedragsdescriptoren, hoewel het huidige onderwijskader voor patiëntcommunicatie het gebruik ervan in het algemeen afraadt. Ongeveer een derde van de beoordelingen van studenten ging over de inhoud, de verzamelde informatie dus, en ongeveer de helft over de kwaliteit van de communicatieve vaardigheden. Circa 10\% richtte zich op de toepasselijkheid van de gebruikte communicatieve vaardigheden; het waren voornamelijk de betere studenten die zich van dit soort beoordelingen bedienden. Daarnaast bleken de betere presteerders hun scènes vaker als 'onvoldoende'te beoordelen dan de slechtere presteerders.

Studie 4 stelde onderzoeksdoel drie aan de orde dat betrekking had op de aanwijzingen die supervisors gebruiken bij het voorbereiden van feedback over anamneseafname. Het model van anwijzinggebruik voor het afnemen van anamneses werd daarom uitgebreid zodat het aanwijzinggebruik gemodelleerd kon worden met externe beoordelingen. Het model werd getoetst door het aanwijzinggebruik door artsen te vergelijken met dat van niet-artsen. Beide groepen maakten vaker gebruik van

3 JOSs = Judgements of Satisfaction 
waarneembare aanwijzingen dan van zich voordoende aanwijzingen, zoals subjectieve gevoelens en mentaliserende aanwijzingen, maar het waren voornamelijk de artsen die zich van omissieaanwijzingen bedienden. In vergelijking met de niet-artsen beschreven de artsen meer scènes die negatieve prestaties lieten zien.

Uit de vier studies kan een aantal hoofdbevindingen, theoretische en methodologische bijdragen en praktijkbijdragen worden afgeleid. De belangrijkste bevindingen van Studie 1 leidden tot de ontwikkeling van het op zelfregulatie gerichte gespreksmodel voor anamneses. Om de complexiteit van de verschillende kennis- en vaardigheidsdomeinen te bevatten, werd, zoals hierboven al beschreven, het afnemen van een anamnese voorgesteld als een reeks van drie begripsproblemen. De verschillende kennis en vaardigheden die nodig zijn om deze problemen op te lossen zijn onderverdeeld in drie schema's, welke op hun beurt uit drie subschema's bestaan. Dit model geeft aan dat wanneer we het hebben over het stimuleren van correcte zelfbeoordelingen ter verbetering van de zelfregulatie het van cruciaal belang is dat we weten welke schema's en subschema's er momenteel geleerd en gemonitord moeten worden. Het heeft alleen zin om zelfcontrolebeoordelingen met externe normen te vergelijken als beide gericht zijn op dezelfde schema's of subschema's. De implicaties voor de praktijk kunnen als volgt worden samengevat. Om ervoor te zorgen dat studenten beter in staat zijn de reeks van drie begripsproblemen van anamneses succesvol op te lossen, moeten docenten hun studenten een overzicht van deze problemen geven. Wat ook een prioriteit zou moeten zijn van klinische supervisors is om beginnende studenten te helpen de vereisten van de klinische setting te begrijpen, aangezien dit de basis legt voor het geven van een passende structuur aan de anamnese met de patiënt en daarmee bijdraagt aan het verhaal van de patiënt.

De belangrijkste bevindingen van Studie 2 en Studie 3 inspireerden de ontwikkeling van het model van aanwijzinggebruik tijdens het communiceren met de patiënt. Studenten die van zichzelf beoordeelden hoe goed zij waren in het 'communiceren met de patiënt' maakten overwegend gebruik van de aanwijzingen die door het algemene kader voor aanwijzinggebruik werden voorspeld en die het gevestigde onderwijskader voor patiëntcommunicatie aanbeval, met uitzondering van de summatief-gedragsdescriptoren. Hoewel het gebruik van deze laatste wordt afgeraden, maakten zowel de betere als de slechtere presteerders gebruik van deze aanwijzingen. De betere presteerders daarentegen, integreerden over het algemeen meer verschillende soorten aanwijzingen in hun zelfbeoordelingen tijdens het oefenen van anamneses, met name mentaliserende aanwijzingen. Hieruit kan dus worden opgemaakt dat de betere presteerders de summatief-gedragsdescriptoren die in hen opkwamen als aanleiding gebruikten om dieper te graven en naar relevante waarneembare gedragsaanwijzingen en andere zich voordoende aanwijzingen te zoeken. De aan deze studies gekoppelde implicatie voor de praktijk is dat de betekenis van summatief-gedragsdescriptoren herzien zou moeten worden. In plaats van het gebruik ervan af te raden, zou moeten 
worden benadrukt dat zij gebruikt moeten worden als aanwijzing dat verdere reflectie nodig is.

Relevante bevindingen die het gebruik van aanwijzingen voor het voorbereiden van feedback door artsen vergeleken met dat van niet-artsen (Studie 4) bevelen een op zelfregulatie gerichte feedbackprocedure aan. Beide groepen supervisors maakten bij de beoordeling van de kwaliteit van anamneses adaptief gebruik van waarneembare aanwijzingen, zoals aanbevolen door het onderwijskader voor patiëntcommunicatie waarbinnen zij opgeleid waren. Bij het beoordelen van de manier waarop het bezoek werd vormgegeven gebruikten ze geheugenaanwijzingen en gaven er de voorkeur aan de interviewer te observeren in plaats van de patiënt. Bij het beoordelen van de wijze waarop het verhaal werd aangestuurd verschoven zowel de artsen als de niet-artsen hun aandacht ook richting de patiënt om inzicht te verkrijgen in de interactie. Beide groepen namen ook subjectieve gevoelens en mentaliserende aanwijzingen mee in hun beoordelingen. Omissieaanwijzingen werden echter voornamelijk gebruikt door artsen. Beide groepen bleken goed voorbereid te zijn in die zin dat zij hun observaties communiceerden en dus beschrijvende feedback gaven op de manier zoals aanbevolen door het onderwijskader voor patiëntcommunicatie dat gebruikt wordt om studenten anamnesevaardigheden aan te leren. De implicatie voor de praktijk van deze studie is de suggestie om het proces van feedback geven verder te verbeteren. Supervisors zouden getraind moeten worden in het herkennen van zich voordoende aanwijzingen, zoals subjectieve gevoelens en mentaliserende aanwijzingen, als valide bronnen van feedback. Tevens zouden zij moeten leren deze aanwijzingen te vertalen naar waardevolle metacognitieve stimuli voor studenten, alvorens hun beschrijvende feedback te geven.

De besluiten over de benadering van de drie onderzoeksdoeleinden hebben onvermijdelijk tot beperkingen geleid. Door iemand om een zelfreflectie te vragen kan het object van de studie al veranderd worden; desondanks werd besloten om met dit probleem te leven, omdat leren ook om 'bewuste verwerking' vraagt. Voor het ontwikkelen van een model van aanwijzinggebruik werd besloten om bachelorstudenten geneeskunde te observeren, voornamelijk omdat deze studenten direct beschikbaar waren. Verder onderzoek met bijvoorbeeld andere leeromgevingen en andere groepen studenten is noodzakelijk. Bovendien gebruikte de studie die de betere studenten met de slechtere studenten vergeleek met betrekking tot hun aanwijzinggebruik een casecontrol-ontwerp. Dit houdt in dat er behoefte is an toekomstige cohortstudies die meer inzicht trachten te verkrijgen in de manier waarop aanwijzinggebruik verandert naarmate prestaties ontwikkeld worden. De beschreven theoretische bijdragen laten ook een beperking ten aanzien van onze inhoudsanalytische benadering zien. Deze was anvankelijk ingegeven door het onderscheid tussen inhoudelijke aspecten en procesmatige aspecten zoals bepaald door het onderwijskader voor patiëntcommunicatie. Maar aangezien het theoretische gedeelte van onze studies uitwees dat een meer gedetailleerde structuur voor het afnemen van anamneses wenselijk is, zouden nieuwe 
studies er baat bij hebben als zij een aangepast systeem voor inhoudsanalyse hanteren.

Ten slotte werd geconcludeerd dat het verbeteren van de juistheid van zelfbeoordelingen als voorloper van effectieve zelfregulatie in de eerste plaats vereist dat de complexiteit van het afnemen van anamneses wordt aangepakt. Pas dan kunnen er maatregelen getroffen worden om de wijze waarop elk aspect van het afnemen van anamneses gemonitord wordt, te verbeteren. De literatuur over het communiceren met patiënten en nieuwe resultaten op het gebied van aanwijzinggebruik ten aanzien van 'het communiceren met de patiënt' maakte het voor ons mogelijk om een model van aanwijzinggebruik voor het tweede begripsprobleem ('communiceren met de patiënt') voor te stellen. De metacognitieve stimuli die middels dit model verkregen worden, kunnen worden getoetst op de effecten die zij hebben op de zelfregulatie. Kennis over hoe studenten te ondersteunen bij het oplossen van het eerste begripsprobleem ('communicatiestrategie') en het derde begripsprobleem door hen te helpen de informatie van patiënten met hun medische kennis samen te voegen om zo tot een 'patiëntschema' te komen, zou verder ontwikkeld moeten worden door onderwijskundigen en clinici.

Vanuit een zelfregulatieoptiek zal het verbeteren van het gebruik van waarneembare en op beleving beruste aanwijzingen door studenten bij het beoordelen van de manier waarop zij zelf anamneses afnemen hen helpen om de behoeften van alle betrokkenen beter in evenwicht te brengen. Uiteindelijk zal dit niet alleen leiden tot een verbeterde communicatie met de patiënt, maar ook het klinisch redeneren verbeteren dat zich op de verzamelde informatie baseert. 
Appendix 


\section{VALORISATION ADDENDUM}

This valorization addendum aims to identify opportunities for creating further value from the theoretical and empirical research results presented in this thesis. Results presented in the four studies can serve to guide the educational development of programs for training students' self-monitoring skills. However, given the innovative aspects of our research approach it is recommended to conduct additional independent studies to strengthen the evidence for this guidance.

This thesis expanded an established version of the conversational model of history taking to better model the learning processes related to history taking from a self-regulation perspective. Interpreting history-taking as consisting of three problemsolving tasks results in the newly presented self-regulation oriented conversational model of history-taking. In addition, self-regulation required to comprehend and solve each of the three tasks can be modeled in a more detailed fashion using cue-utilization frameworks. The subsequent sections sketch ideas for creating value by using these two theoretical models for the practice of teaching and learning medical history-taking.

\section{Learning materials supporting self-regulation while learning history-taking The history-taking knowledge and skills map}

Mapping the diverse sub-skills interacting in constituting good history taking for creating the self-regulation oriented conversational model of history-taking made the high complexity of history taking apparent. To perform and practice their history taking effectively students need not only basic 'communication skills' and 'medical knowledge', but also a high level of knowledge about how the medical team interacts in the clinical setting.

Thus, a first product creating value from this result could be a map visualizing the sub-skills and knowledge. Such a map facilitates students' and supervisors' orientation on what has already been achieved and what still needs to be learned.

\section{Textbook chapter on self-regulated learning of history-taking during clinical placement}

Around the knowledge and skills map, a textbook chapter about how to best continue learning history-taking during clinical placements could be developed. This chapter should accompany common learning materials used in early communication skills training in medical school, and should outline how the diverse knowledge elements and skills needed for history-taking interact, which of these knowledge and skills have already been trained in communication skills training, and what knowledge has to be acquired when entering a clinical placement. Use of the knowledge and skills map that outlines to students where they 'stand' after history-taking training in the classroom, and what they need to learn when entering a new clinical setting, might contribute to establishing a working and learning attitude supporting self-regulation. This entails 
students' showing their interest in a clinical department's work routines to identify what they need to learn and what they can learn in a specific department. It also includes students expressing clearly what they feel and what they do not feel ready to do, and it entails students asking for help in order to learn new things in the clinic.

\section{Train-the-trainer material on integrating undergraduate medical-students' skills efficiently in the medical team?}

A similar study text, titled How to efficiently integrate undergraduate medicalstudents' skills in the medical team? should be developed accompanying the train-the trainer materials for clinical supervisors. This is necessary because students' efforts in self-regulation are influenced by their supervisors. When students approach a supervisor in an attempt to find out which specific information (e.g., on current medication) they have to gather when interviewing a patient, it supports and reinforces their self-regulation when their asking for help is well received by the majority of their supervisors. Such a text outlines what supervisors can expect students of this level of education to know and to be able to do, and what information the clinic needs to provide to new students to integrate them efficiently in their medical team. Using the knowledge and skills map to outline for clinical supervisors where their students 'stand' with respect to their historytaking skills, might contribute to establishing the supportive workplace-based learning environment that students need to become and stay engaged in learning.

\section{Learning materials supporting cue-utilisation for history-taking}

\section{Facilitating accurate self-judgment with a checklist scaffolding self-monitoring} Within this thesis the self-regulation oriented conversational model of history-taking was used to theoretically explore what observable behavior, what information from memory, and what experiential information is available to students as cues when self-monitoring the three learning processes related to history taking. The resulting cue-utilization models indicate that the current practice of using checklists designed for assessing students' history taking performance are not necessarily helpful when students self-monitor their learning. Checklists such as the well-known Calgary Cambridge guide to the medical interview by Kurz, Silverman Benson and Draper generally require an observer to rate if specific behavior has been shown by the student, sometimes the appropriateness of the behavior shown has to be rated additionally (e.g., Student uses empathy to communicate appreciation of the patient's feelings or predicament - goodladequate/not adequatelnot done). When students use such checklists for learning, they simply replace "student" with "I". However, from a learning point of view this practice might not be helpful in informing their learning, as it requires them to be able to look what is behind using empathy adequately, which is hard to recognize. A new learning-oriented checklist inspired by the cue-utilization framework might provide more specified scaffolds to facilitate accurate self-monitoring by steering student's attention towards cues relevant for accurate self- 
judgment. The basic design principle for compiling a learning-oriented checklist is to guide students to relevant cues that provide a basis for more accurate self-judgments.

A prompt such as Identify a scene during your last encounter where your patient expressed feelings or predicament and describe it using keywords draws students' attention towards observable patient behavior and towards their own interpretation of how their patient might have felt in the situation. The cognitions related to providing the required keywords then provide the basis for self-judging their performance accurately by answering a question such as: How do you rate your own reaction following the patient's expression of feelings or predicament? (goodladequatelnot adequatelnot done).

\section{Facilitating accurate external-judgments with a checklist scaffolding monitoring}

Consequently, the newly developed cue-utilization frameworks can also be used to facilitate accurate external judgments. Using the established checklists for selfassessment as described above also requires supervisors to be able to look at what is behind items such as 'using empathy adequately' to be able to judge accurately. Thus, also supervisors' accuracy in rating students' performance may be improved with a scaffolded checklist. A prompt such as Mark each scene where the patient expressed feelings or predicament. Write one illustrative keyword and judge adequacy of student's response might result in a written observation protocol such as $\mathbf{x}$ : puzzled $(-) ; \mathbf{x}$ : ?? (--); $\mathbf{x}$ : offended (+/-). The resulting overall judgment 'not adequate' for the item Student uses empathy to communicate appreciation of the patient's feelings or predicament is thus well informed and reproducible.

\section{Use subjective experiential information to give feedback - rethinking the role of personality adjectives}

Within this thesis the cue-utilization framework associated with the second process described in the self-regulation oriented conversational model of history-taking (communicating with the patient) was tested. Students and supervisors were found to include most cues in their (self)-monitoring as predicted by the model and recommended by communication skills teachers, except for the emerging experiential cue 'summative behavior descriptors'. They are comparable to personality adjectives whose usage for feedback-giving is discouraged by communication skills teachers. However, students used them a lot when elaborating on their monitoring, but supervising doctors and nondoctors seemed to be reluctant in using them when monitoring. Rethinking the practice of discouraging usage of personality adjectives for feedback giving might be necessary. Experiential cues such as personality adjectives emerge naturally in consciousness when encountering other human beings. Clearly their noticing should not be the endpoint of monitoring and thus they should not be communicated as 'judgment' or used as a 'self-judgment'. Instead, personality adjectives should serve for students as well as for supervisors as a 'cue' to further explore their behavioral origin. 


\section{Conclusion}

To conclude, this thesis provides an example of how to merge theoretical considerations concerning learning of complex skills with the practical context of learning history-taking in medical school and in the workplace. It might lay the foundation for totally new types of educational interventions targeting at boosting students' selfregulated learning of history-taking in the workplace. 
Appendix 


\section{ACKNOWLEDGEMENTS}

Progressing with this project was only made possible through the dedication, cooperation and patience of a number of people. I would like to express my thanks especially to my supervisors Prof. Dr. Jeroen (J.J.G.) van Merrienboer and Prof. Anique (A.B.H.) de Bruin. Working together with them on manuscripts for study protocols and manuscripts for papers allowed me to experience the art of giving feedback at its best.

I owe a special thank you to the School of Health Professions Education (University Maastricht) for providing the framework to combine highly individualized, distance-based study activities with inspiring structured classroom based activities, such as SHE-Academy. Also outstanding is the support the school provides in navigating the administrative and organisational challenges an international student faces in a distancebased study program.

Also I would like to express my thanks to Teaching Center (Medical University of Vienna) for allowing me to carry out the research related to this project. I am especially grateful to all my undergraduate medical students, whom I had the pleasure to work with in the history-taking course, and to all the communication skills teachers, for their willingness to give their data for this research.

Thank you to all of you who made this project possible! You contributed to transforming my work on this project into a unique learning experience and into something to remember. 
Appendix 


\section{CURRICULUM VITAE}

Michaela Wagner-Menghin

\section{PRESENT POSITION}

Academic Rank:

Department/Division:
DATE June, 2019

\section{EDUCATION}

2012

Medical Education at Medical University Vienna (Certificate Program, 7.5 ECTS)

1998 Propaedeutic Course for Psychotherapy, (part time program);

ÖAGG-Austrian study group for group psychotherapy and group dynamics, Vienna

1995-1997 Postgraduate course in clinical psychology and health psychology, (part time program), GKPP- Critical Psychologists' Association, Vienna

1995-2000 Dr.rer.nat in Psychology (part time doctorate program, equals 2 year full-time program) University of Vienna

1990-1995 Mag.rer.nat in Psychology, (5 year full-time master program); University of Vienna

\section{PROFESSIONAL EXPERIENCE}

Academic

02/2009-present

03/2006-01/2009

$10 / 2004-02 / 2006$

$12 / 2002-09 / 2003$

$2002 / 2003$
Assistant PostDoc, (Associate Professor since 01.2014);

Medical University Vienna, Department for Medical

Education (Now: Teaching Center)

University Assistant (II); University of Vienna, Faculty of

Psychology, Department of Developmental Psychology and

Psychological Assessment

Part-time teaching contract; University of Vienna, Faculty of

Psychology, Department of Developmental Psychology and

Psychological Assessment

University Assistant (II); University of Vienna, Faculty of Psychology, Department of Developmental Psychology and Psychological Assessment

Research visit; Australian Council of Educational Research (ACER); Melbourne, Australia (01/2003-03/2003 and 06/2002-09/2002) 
12/1998-11/2002 University Assistant (I); University of Vienna, Institute of Psychology, Department of Psychometrics and Differential Psychology

10/1996-11/1998 Part-time teaching contract; University of Vienna, Institute of Psychology, Department of Psychometrics and

Other Differential Psychology

03/1996-11/1998 Scientific officer (deputy department head of Psychology Department since 03/1997), Dr.G.Schuhfried GmbH, Mödling (Austria)

10/2003-09/2004 Maternity leave

Certification

1999

Clinical Psychologist and Health Psychologist (accredited by the Austrian Ministry of Health, GZ 225.355/0-VIII/D/14/99), Vienna

$09 / 2008$ Venia docendi (Habilitation) für das Fach Psychologie [Postdoctoral lecture qualification in psychology] at University of Vienna (Privatdozent). Title of the integrative paper accompanying the application: Working Style - a disregarded construct in psychological assessment. 
Appendix 


\section{SHE DISSERTATION SERIES}

McGill, D. (29-5-2019) Supervisor competence as an assessor of medical trainees. Evaluating the validity and quality of supervisor assessments

Van Rossum, T. (28-2-2019) Walking the tightrope of training and clinical service; The implementation of time variable medical training

Amalba, A. (20-12-2018) Influences of problem-based learning combined with community-based education and service as an integral part of the undergraduate curriculum on specialty and rural workplace choices

Melo, B. (12-12-2018) Simulation Design Matters; Improving Obstetrics Training Outcomes

Olmos-Vega, F. (07-12-2018) Workplace Learning through Interaction: using sociocultural theory to study residency training

Chew, K. (06-12-2018) Evaluation of a metacognitive mnemonic to mitigate cognitive errors

Sukhera, J. (29-11-2018) Bias in the Mirror. Exploring Implicit Bias in Health Professions Education

Mogre, V. (07-11-2018) Nutrition care and its education: medical students' and doctors' perspectives

Ramani, S. (31-10-2018) Swinging the pendulum from recipes to relationships: enhancing impact of feedback through transformation of institutional culture

Winslade N. (23-10-2018) Community Pharmacists' quality-of-care metrics. A prescription for improvement

Eppich, W. (10-10-2018) Learning through Talk: The Role of Discourse in Medical Education

Wenrich, M. (12-09-2018) Guided Bedside Teaching for Early Learners: Benefits and Impact for Students and Clinical Teachers 
Marei, H. (07-09-2018) Application of Virtual Patients in Undergraduate Dental Education

Waterval, D. (26-04-2018) Copy but not paste, an exploration of crossborder medical curriculum partnerships

Smirnova, A. (04-04-2018) Unpacking quality in residency training and health care delivery

Hikspoor, J. (05-12-2017) Development of the heart and vessels in the caudal part of the human body

Boymans, T. (06-10-2017) Hip arthroplasty in the very elderly: anatomical and clinical considerations

Zaidi, Z. (04-10-2017) Cultural hegemony in medical education: exploring the visibility of culture in health professions

Harrison, C. (20-09-2017) Feedback in the context of high-stakes assessment: can summative be formative?

Mekonen, H. (30-06-2017) Development of the axial musculo-skeletal system in humans

Taylor, T. (29-03-2017) Exploring Fatigue as a Social Construct: Implications for Work Hour Reform in Postgraduate Medical Education

McLellan, L. (29-03-2017) Prescribing the right medicine: Perspectives on education and practice

Ignacio, J. (09-02-2017) Stress Management in Crisis Event Simulations for Enhancing Performance

Bolink, S. (19-01-2017) Functional outcome assessment following total hip and knee arthroplasty; Implementing wearable motion sensors 
ISBN: 978-94-6380-465-3

Design by: Bregje Jaspers, ProefschriftOntwerp.nl

Printed by: ProefschriftMaken, www.proefschriftmaken.nl

(C) 2019, Michaela Wagner-Menghin 